\title{
Evidence for the important role of inflammation in xenotransplantation
}

\author{
Juan Li ${ }^{1,2}$, Hidetaka Hara², Yi Wang ${ }^{1}$, Charles Esmon³ ${ }^{3}$ David K. C. Cooper ${ }^{2}$ and Hayato Iwase ${ }^{2 *}$
}

\begin{abstract}
There is increasing evidence of a sustained state of systemic inflammation after pig-to-nonhuman primate (NHP) xenotransplantation (that has been termed systemic inflammation in xenograft recipients [SIXR]). Increases in inflammatory markers, e.g., C-reactive protein, histones, serum amyloid A, D-dimer, cytokines, chemokines, and a decrease in free triiodothyronine, have been demonstrated in the recipient NHPs. The complex interactions between inflammation, coagulation, and the immune response are well-recognized, but the role of inflammation in xenograft recipients is not fully understood. The evidence suggests that inflammation can promote the activation of coagulation and the adaptive immune response, but the exact mechanisms remain uncertain. If prolonged xenograft survival is to be achieved, anti-inflammatory strategies (e.g., the administration of anti-inflammatory agents, and/or the generation of genetically-engineered organ-source pigs that are protected from the effect of inflammation) may be necessary to prevent, control, or negate the effect of the systemic inflammation that develops in xenograft recipients. This may allow for a reduction in the intensity of exogenous immunosuppressive therapy. If immunological tolerance to a xenograft is to be obtained, then control of inflammation may be essential.
\end{abstract}

Keywords: Inflammation, Non-human primates, Pigs, Xenotransplantation

\section{Introduction}

Organ transplantation is one of the medical success stories of the past 70 years, but there remain insufficient organs from deceased human donors to treat all of the patients who might benefit. For example, in the USA at present there are approximately 120,000 patients awaiting an organ of one sort or another, and yet this year only approximately 10,000 deceased human donors will become available, providing an average of three or four organs per donor [1].

The lack of human organs could be obviated if a suitable animal source of organs were available. For a number of logistic and other reasons, the pig has been identified as a potential source of organs for clinical transplantation [2]. The field of xenotransplantation (cross-species transplantation) has therefore been extensively investigated during the past 35 years [3]. Although organs from wild-type (i.e., genetically-unmodified) pigs transplanted into humans or nonhuman primates (NHPs) are rejected within minutes [4], our ability to genetically-engineer the pig to protect its

\footnotetext{
* Correspondence: hiwase@uabmc.edu

${ }^{2}$ Xenotransplantation Program, Department of Surgery, University of Alabama at Birmingham, Birmingham, AL, USA

Full list of author information is available at the end of the article
}

organs from the primate immune response has resulted in life-supporting kidney or heart graft survival in NHPs extending to many months or even more than a year [5-9]. One of the barriers that has had to be overcome, but continues to be problematic, is the inflammatory response to the presence of a pig organ.

Inflammation is part of the complex biological response of body tissues to harmful stimuli, and is observed in various diseases, e.g., inflammatory disease [10], infection [11], atherosclerosis [12]. The release of appropriate pro-inflammatory cytokines and chemokines is necessary for protective immunity, but production of these factors in excess can result in various pathological states [13]. An inflammatory response follows ischemia-reperfusion injury after organ transplantation [14]. This may play an important role in initiating the allo-immune response [15], and in the development of allograft vasculopathy [16].

There is increasing evidence of a systemic inflammatory response to the presence of a pig xenograft ('systemic inflammation in xenograft recipients' [SIXR]) [17-19]. Inflammation promotes activation of coagulation [17-21] and of the immune response $[17,18]$ that develop after xenotransplantation [22, 23]. In organ xenograft recipients, 
C-reactive protein (C-RP) increases before the development of consumptive coagulopathy or a $\mathrm{T}$ cell response $[17,18]$. Infiltrating innate immune cells express tissue factor, which plays a role in initiating coagulation [24]. The development of $T$ cell tolerance is inhibited by inflammation $[22,25]$.

We here review the evidence of a prolonged systemic inflammatory response to a xenograft, and consider what steps can be taken to prevent or reduce it. We have primarily drawn on our own observations, but have supplemented these by a review of the literature.

\section{Evidence for a sustained inflammatory response in xenograft recipients (SIXR) (Table 1)}

$C$-reactive protein $(C-R P)$ is an acute phase protein synthesized largely by hepatocytes in response to proinflammatory cytokines, in particular interleukin-6 (IL-6) [31]. C-RP provides the first line of defense to an invasive pathogen, and can promote activation of complement, bacterial capsular swelling, and phagocytosis [32]. It is a marker of early infection, and provides an easy objective parameter [33]. Moreover, C-RP mRNA expression increases in the presence of acute rejection of a renal allograft [34]. C-RP can contribute both to host defense against infection and enhancement of inflammatory tissue damage.

After pig-to-baboon organ transplantation, C-RP is increased for several months, suggesting a persisting inflammatory state $[13,19,26]$ (Fig. 1a), and is deposited in the transplanted pig kidney [18] (Fig. 1b). Whether this is secondary to initial antibody binding remains uncertain.

Serum amyloid $A(S A A)$ is a major acute-phase protein and an inflammation-related marker in tuberculosis, rheumatoid arthritis, Crohn's disease, and in various cancers [35, 36]. SAA is also a sensitive marker of acute allograft rejection [37]. Hepatocytes are a major source of SAA [38]. Elevated SAA results from increases in circulating serum interleukin-6 (IL-6) and tumor necrosis factoralpha (TNF- $\alpha)$ [39]. The inflammation-associated cytokines produced by endothelial cells (ECs), lymphocytes, specially-activated monocytes, and macrophages stimulate amyloid A synthesis [35, 40]. In turn, SAA may induce the release of some pro-inflammatory cytokines e.g., TNF- $\alpha$, IL-1 $1 \beta$, and the chemokine IL- $8[41,42]$. However, SAA can also induce the secretion of chemokines that might suppress inflammation locally [43], and mobilizes phospholipids and cholesterol for cell repair [44].

After pig-to-baboon organ xenotransplantation, significant increases in SAA have been observed during antibody-mediated rejection (Fig. 2) or when a consumptive coagulopathy or infection is developing [26, 27]. Amyloid A is deposited in the transplanted pig kidney [28]. Although the current method of measuring SAA is not fully quantitative, it is a simple and rapid indicator of the inflammatory state, allowing early investigation, e.g., for rejection, infection, or other complications.

Extracellular histones play a key role in inflammation [45]. In vivo, they result in EC dysfunction (e.g., neutrophil margination, hemorrhage, thrombosis), and in vitro they are cytotoxic to ECs [45]. Five types of histones have been identified [46, 47]. Release of histones can be triggered by sepsis, trauma, chemical toxicity, transplant injury, and ischemia-reperfusion [48]. They bind to Toll-like receptors (TLRs) of various cells, e.g., platelets, red blood cells [49], which in turn induce NETosis (cell death, release of granular contents into the extracellular

Table 1 Evidence for systemic inflammation in xenograft recipients (SIXR)

\begin{tabular}{|c|c|c|c|}
\hline & Indicators of inflammation & $\begin{array}{l}\text { Change when associated with } \\
\text { xenotransplantation }\end{array}$ & References \\
\hline \multirow[t]{12}{*}{ In vivo } & C-reactive protein (C-RP) & $\uparrow$ & {$[13,19,26]$} \\
\hline & Serum amyloid A (SAA) & $\uparrow$ & {$[26-28]$} \\
\hline & Histones & $\uparrow$ & [26] \\
\hline & D-dimer & $\uparrow$ & {$[6,13,19]$} \\
\hline & Tumor necrosis factor-alpha (TNF-a) & $\uparrow$ & [18] \\
\hline & Interferon-gamma (IFN- $\gamma)$ & $\uparrow$ & [18] \\
\hline & Interleukin-6 (IL-6) & $\uparrow$ & {$[13,18]$} \\
\hline & Interleukin-8 (IL-8) & $\uparrow$ & {$[13,18]$} \\
\hline & Interleukin-12 (IL-12) & $\uparrow$ & [18] \\
\hline & Monocyte chemotactic protein-1 (MCP-1) & $\uparrow$ & {$[13,18]$} \\
\hline & Soluble CD40 ligand (sCD40L) & $\uparrow$ & {$[13,29]$} \\
\hline & Free triiodothyronine (fТ3) & $\downarrow$ & {$[6,30]$} \\
\hline \multirow[t]{2}{*}{ In vitro } & Platelet aggregation & $\uparrow$ & [26] \\
\hline & Endothelial cell apoptosis & $\uparrow$ & [26] \\
\hline
\end{tabular}




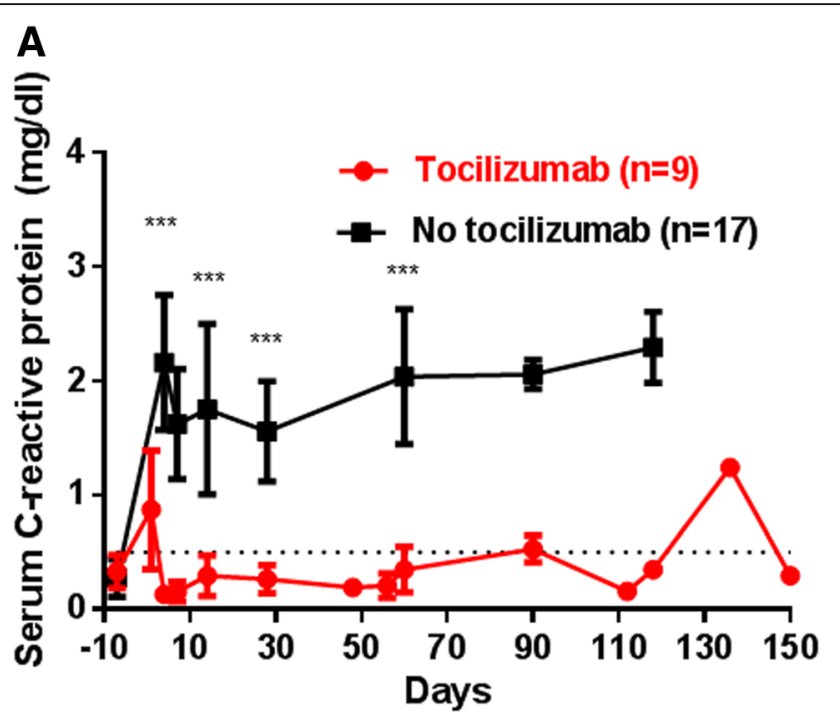

B

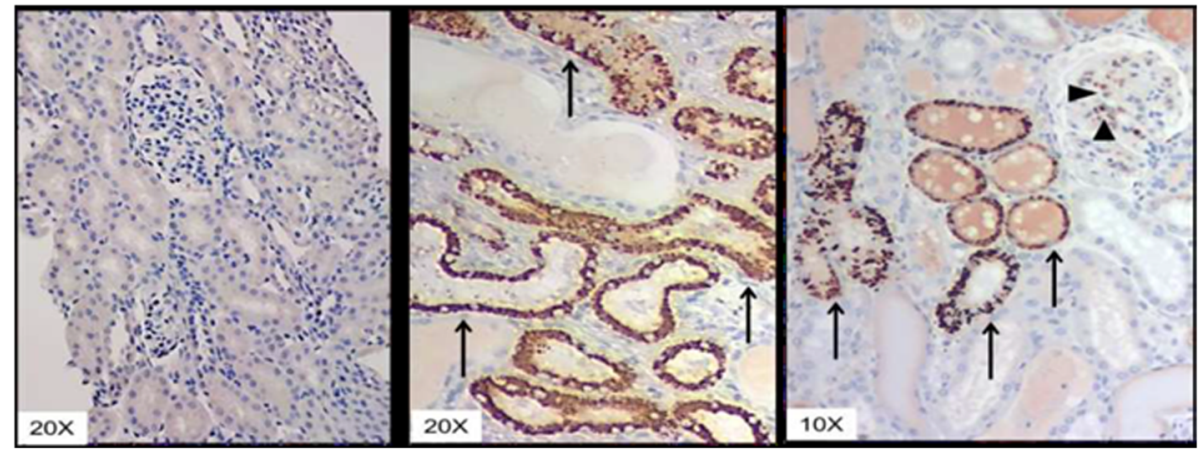

Fig. 1 a C-RP in baboons with pig artery patch $(n=9)$ or organ $(n=17)$ grafts. Levels of C-RP in baboons before (day 0$)$ and after pig organ or artery patch transplantation. (Black line = without tocilizumab therapy; Red line = with tocilizumab therapy.) The mean level of C-RP in the tocilizumab-treated baboons remained $<0.5 \mathrm{mg} / \mathrm{dL}$ from day 4 , which (on days $7,14,28$, and 60 ) was significantly lower than in baboons not receiving tocilizumab (day $7,0.2$ vs $1.6 \mathrm{mg} / \mathrm{dL}, P<0.001$; day $14,0.3$ vs $1.8 \mathrm{mg} / \mathrm{dL}, \mathrm{P}<0.001$; day $28,0.3 \mathrm{vs} 1.6 \mathrm{mg} / \mathrm{dL}, \mathrm{P}<0.001$; and day $60,0.3 \mathrm{vs} 2.0 \mathrm{mg} / \mathrm{dL}, P<0.01$, respectively). ${ }^{* * P}<0.01$; $\left.{ }^{* *} P<0.001\right)$. Tocilizumab treatment therefore prevented an increase in C-RP after xenotransplantation. (The rise in C-RP on day 136 in one of the baboons in the tocilizumab-treatment group was associated with the onset of systemic infection.) (Reprinted with permission from ref. [26]). $\mathbf{b}$ C-RP deposition in pig kidneys transplanted into baboons, an indicator of the inflammatory response to the graft. (Left panel) At 30 min after reperfusion of an a1,3-galactosyltransferase gene-knockout (GTKO) pig kidney graft, no C-RP deposition was detected. In two different kidneys at the time of euthanasia (middle and right panels), C-RP deposition was detected in the glomeruli (arrow heads, right panel) and tubules (arrows, middle and right panels). Our data suggest that both the xenograft and the recipient contribute to C-RP production. (We detected minimal C-RP in NHPs undergoing heart allotransplantation [not shown]). (Reproduced with permission from ref. [18])

space). This in turn increases histone release and amplifies inflammation [50-57].

The direct prothrombotic activity of histone-DNA complexes increases inflammatory cytokine formation, and fosters thrombotic responses by activating TLRs 2 , 4, and 9 [48]. Moreover, inflammatory cytokines downregulate thrombomodulin, induce tissue factor, and upregulate plasminogen activator inhibitor [48]. Histones can also cause direct platelet activation $[53,58]$. Their levels increase in xenograft recipients when there is evidence for inflammation and coagulation dysfunction [26]. In the absence of IL-6-receptor blockade (with tocilizumab), the mean serum histone level after pig organ transplantation rises significantly [26] (Fig. 3a). A decrease in the number of neutrophils might reduce extracellular histone release $[59,60]$. In in vitro studies, histone-induced porcine EC apoptosis/death was significantly reduced by an inhibitor of nuclear factor kappa B (NF-kB), parthenolide (Fig. 3b) [26]. EC apoptosis is observed in many inflammatory and immune disorders [61].

$D$-dimer is a protein product of cross-linked fibrin degradation. An elevated blood concentration of Ddimer is observed in intravascular coagulation and thrombotic disease [62]. D-dimer may promote the inflammatory cascade by activating neutrophils and 


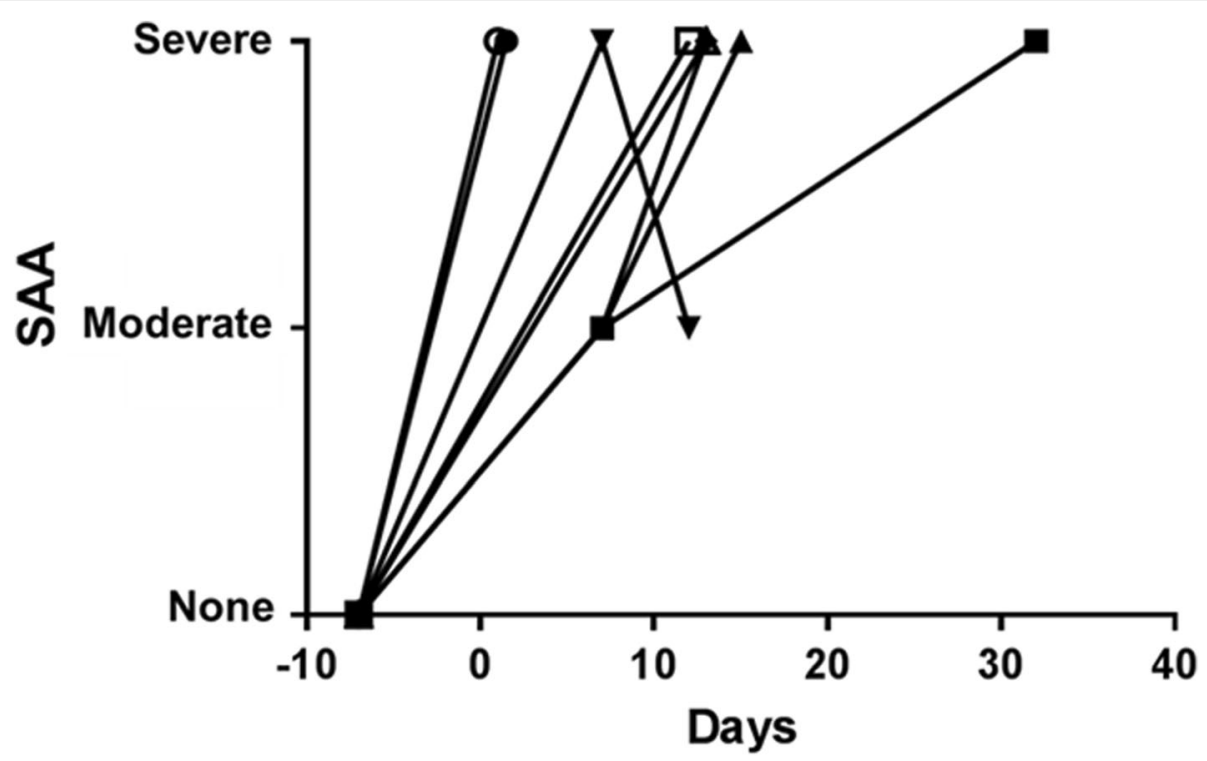

Fig. 2 Serum amyloid A (SAA) in baboons with pig kidney grafts that failed within the first post-transplant month. The SAA increased immediately after pig kidney transplantation, and never returned to pre-transplant levels. Other measurements indicated that a state of inflammation had developed

monocytes, inducing secretion of inflammatory cytokines (e.g., IL-6) [62-65].

D-dimer may also be a marker of inflammation [19, 64, 66, 67], and may rise when a xenograft is failing (Fig. 4) [19].

Pro-inflammatory cytokines/chemokines help to resist infection, but may induce systemic inflammation $[68,69]$. In in vitro studies, porcine IL- 6 , IL- $1 \beta$, and TNF- $\alpha$ activated human umbilical vein ECs (HUVECs) [70]. Pig aortic ECs (pAECs) can be significantly activated by human IL-6, IL-17, IL-1 $\beta$, and TNF- $\alpha$ [70]. For example, (i) human IL-17, IL-1 $\beta$, and TNF- $\alpha$ increased the expression of adhesion molecule genes (e.g., E-selectin, VCAM-1, and ICAM-1), (ii) human IL-6, IL-17, IL-1 $\beta$, and TNF- $\alpha$ induced chemokines (e.g., IL-8 and MCP-1) and increased tissue factor expression, and (iii) expression of swine leukocyte antigen (SLA) class-I was induced by human IL-1 $\beta$ and TNF- $\alpha$ [70]. All of the above cytokines/chemokines are likely to promote inflammation and coagulation in response to a xenograft.

In the absence of immunosuppressive therapy, increases in certain cytokine levels are seen after xenotransplantation, but not when immunosuppressive therapy is administered [18] (Fig. 5a,b).

Inflammation plays a key role in platelet activation and aggregation [71], which in turn plays an important role in the dysregulation of coagulation seen after xenotransplantation [72]. Extracellular histones bind to TLRs, particularly to TLR2 and TLR4, on platelets, which results in platelet aggregation [51, 53]. In humans, the cytokine, IL-17, can promote platelet activation and aggregation through the ERK2 and P53 signaling pathways [73, 74], although the exact mechanism remains unclear [75]. Recipient platelets might also be activated by binding directly to pig ECs [76]. Human platelets can upregulate tissue factor expression after contact with pAECs in the absence of human serum or antibodies, which can lead to coagulation through thrombin production [77].

There is a relationship between a low plasma free triiodothyronine (fT3) and inflammation [78-82]. Plasma fT3 falls following brain death [83, 84], and major surgical procedures, especially heart surgery on cardiopulmonary bypass $[85-89]$.

In recipient baboons undergoing pig heart, kidney, liver, and artery patch xenotransplants, fT3 falls rapidly, and takes several days to return to pre-transplant levels [26] (Fig. 6). A negative correlation between serum IL-6 and TNF- $\alpha$ with thyroid hormone concentrations has been reported [80]. A persisting low level is almost certainly associated with an inflammatory response to a xenograft [26].

\section{Evidence for the relationship between inflammation and coagulation in xenograft recipients}

Until recently, a major barrier to successful pig organ transplantation in NHPs was dysregulation of coagulation resulting from excessive thrombin generation [9093]. The activation of thrombin receptors amplifies production of the chemokine, CCL18, and the pulmonary activation-regulated chemokine by mature dendritic cells [94]. Thrombin can upregulate ICAM-1 mRNA and 

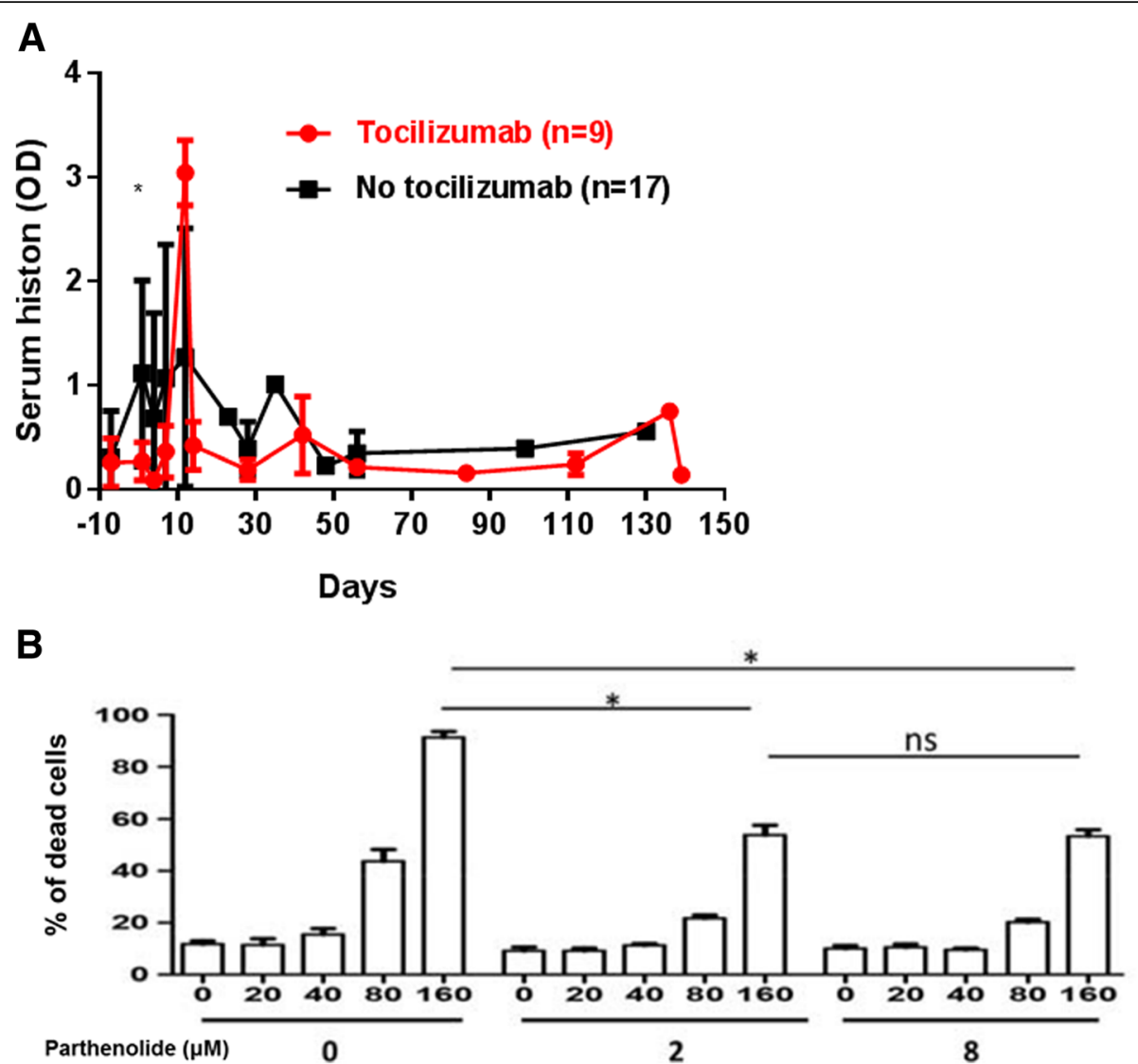

Fig.3 a Serum extracellular histone levels in baboons with pig artery patch grafts. In the absence of tocilizumab therapy, the mean serum histone level was higher on post-transplant day 1 than in baboons receiving tocilizumab (day $1,1.2$ vs. $0.3,{ }^{*} P<0.05$ ), excluding 2 baboons that required euthanasia on day 12 for consumptive coagulopathy. (Black line = without tocilizumab therapy; Red line = with tocilizumab therapy.) Tocilizumab treatment appeared to prevent the sustained histone increase seen after xenotransplantation. (Reprinted with permission from ref. [26]). $\mathbf{b}$ In vitro histone-induced porcine endothelial cell apoptosis/death is influenced by NF-KB inhibition. The NF-KB inhibitor, parthenolide (at 2 and $8 \mu \mathrm{M})$, significantly reduced histone (160 $\mu \mathrm{g} /$ $\mathrm{mL}$ )-induced cell apoptosis/death (mean percentage apoptosis/death of $91.4 \%$ vs $54 \%$, respectively; both $\mathrm{P}<0.05$ ). There was no significant difference in the protective effect of parthenolide at concentrations of 2 and $8 \mu \mathrm{M}$ (mean percentage apoptosis/death of $54 \%$ at both concentrations). (Reprinted with permission from ref. [26])

induce ICAM-1 expression on monocytes in vitro [95], and by activating NF-kB [96].

It is well-known that inflammation contributes to activation of coagulation dysfunction [17, 18, 70, 97, 98]. Tissue factor is not only a promoter of thrombin, but also a marker of inflammation [99, 100]. TNF- $\alpha$ [101], IL-6 [102], and C-RP [103] increase tissue factor expression on innate immune cells, which in turn promotes the activation of coagulation $[100,103]$. There is an amplification circuit between coagulation and inflammation which results in activation of inflammatory mediators as well as procoagulant factors [20]. Therefore, therapeutic prevention of inflammation may be a major factor in minimizing coagulation dysregulation after pig organ xenotransplantation.

An important observation made recently indicates that, when pig vascular ECs expressing only natural pig thrombomodulin (which also has an anti-inflammatory effect) are activated by TNF- $\alpha$, the expression of thrombomodulin is significantly downregulated (Fig. 7a) [98]. This suggests that, when a pig organ is exposed to inflammation (which is universal after a pig organ transplant into a NHP), thrombotic microangiopathy is likely to develop. The absence of the anti-inflammatory effect of human thrombomodulin may result in the early development of consumptive coagulopathy [6]. In contrast, transgenic expression of human thrombomodulin is not downregulated, thus maintaining both its anticoagulant and anti-inflammatory effects (Fig. 7b) [98].

\section{Evidence for the relationship between inflammation and} the immune response in xenograft recipients

The significant increase in certain cytokines/chemokines after xenotransplantation likely results from innate immune cell activity, and may well be a causative factor in xenograft injury $[17,18]$. Inflammation and the innate immune response augment the adaptive immune 


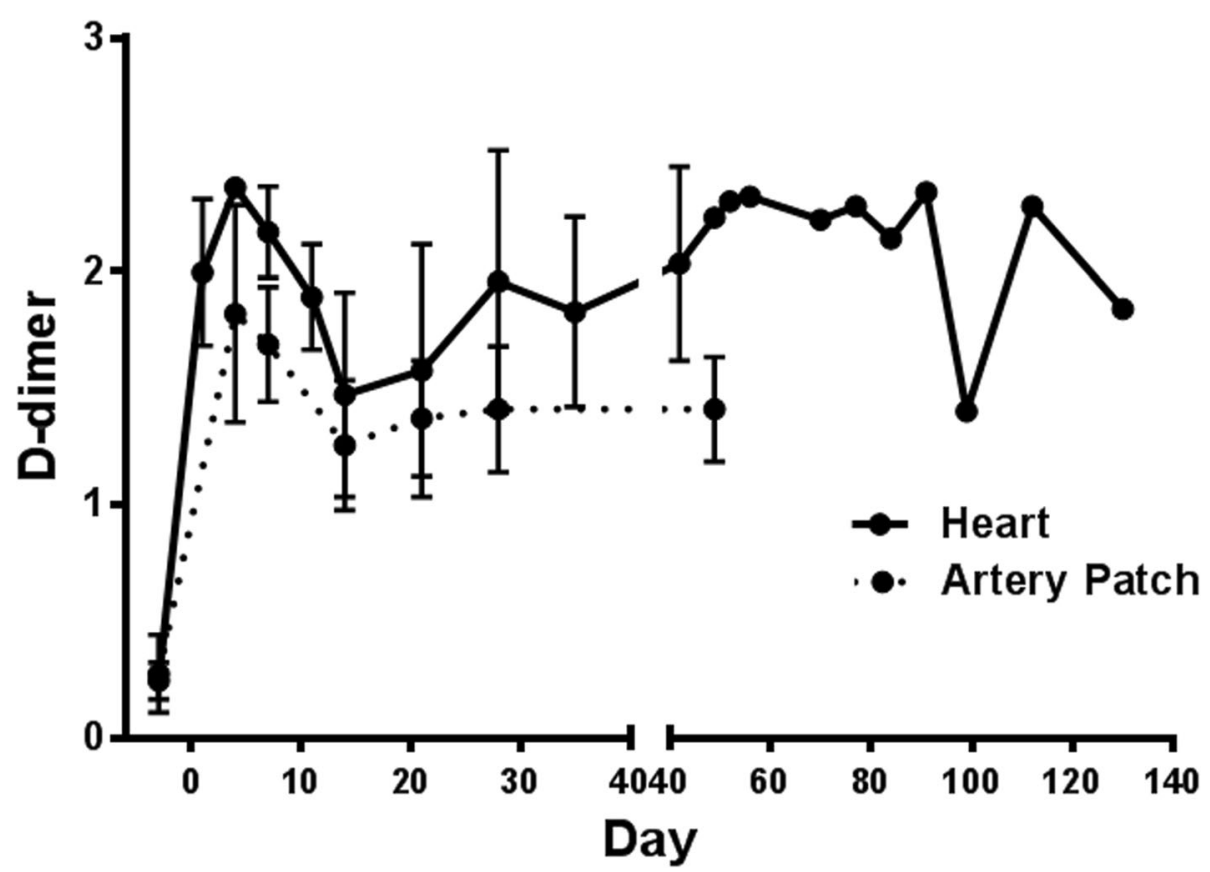

Fig. 4 Changes in D-dimer after pig-to-baboon heart $(n=4)$ or artery patch $(n=14)$ transplantation. In heart recipients, mean D-dimer increased from $<0.5 \mu \mathrm{g} / \mathrm{ml}$ pre-transplant to $>2.0 \mu \mathrm{g} / \mathrm{ml}$ (on post-transplant day 4) and was variable thereafter. In artery patch recipients, mean D-dimer increased from $<0.5 \mu \mathrm{g} / \mathrm{ml}$ pre-transplant to $1.4 \mu \mathrm{g} / \mathrm{ml}$ on post-transplant day $48(P<0.01)$. (Reprinted with permission from ref. [19])

response [70, 98]. Systemic upregulation of inflammatory markers is related to inefficient blockade of the $\mathrm{T}$ cell-dependent adaptive immune response [105].

In an in vitro study, there was a significant increase in the human peripheral blood mononuclear cell (PBMC) proliferative response when pAECs were activated by pig IFN- $\gamma$, supporting the concept that inflammation augments the immune response to a xenograft [106] (Fig. 8a). The induction of T cell tolerance after transplantation is inhibited by inflammation [25]. By affecting the immune response, cytokine and chemokine secretions influence the outcome of allotransplantation [107, 108]. Increased IL-7, IL-8, and IFN- $\gamma$-induced protein 10, chemokine ligand 9, and chemokine ligands 2 and 5 are associated with early allograft dysfunction [109-111].

Inflammation, coagulation, and the immune response have a complex inter-relationship [23, 50]. For example, thrombin activates the human cellular response to pig cells in vitro, and induces a $\mathrm{T}$ cell proliferative response to the same extent as IFN- $\gamma$ activation (Fig. 8b) [97].

\section{Potential strategies to prevent inflammation in xenotransplantation recipients}

Several strategies aimed at preventing or reducing excessive inflammation after xenotransplantation have been tested, some of which are clinically-approved.

\section{Drug therapy (Table 2)}

\section{Corticosteroids}

Corticosteroids activate several genes, including inhibitors of NF- $\kappa$ B, which has an anti-inflammatory effect [120]. After their administration to pig heart xenograft recipients, the levels of IL-6, IL-8, and MCP-1 were reduced [13]. However, D-dimer remained increased, irrespective of corticosteroids and/or anti-inflammatory therapy, suggesting that an inflammatory response persisted [13].

\section{Anti-complement agents}

Although cobra venom factor (CVF) is primarily administered to deplete complement [121], MCP-1, IL-8, and IL-6 are reduced after its administration [13]. After cobra venom factor administration in baboons with pig artery patch grafts, IL-6, IL-8, and MCP-1 remained lower than, or comparable to, pre-transplant levels [13]. Eculizumab is an anti-C5 humanized monoclonal antibody and inhibits the terminal complement effector pathway by preventing its cleavage by the $\mathrm{C} 5$ convertase [122]. It modifies the cytokine profile by increasing IFN- $\gamma$ and IL-17 and lowering IL-4. [123-125]. Cp40, a cyclic 14-amino acid peptide, is a complement inhibitor that inhibits the generation of pro-inflammatory effectors (e.g., TNF- $\alpha$, IL-1 $\beta$, and IL-17) through inhibiting the activation of C3 [126, 127]. C1-inhibitor is the only known plasma protein inhibitor of serine proteases, $\mathrm{C} 1 \mathrm{~s}$ and $\mathrm{C} 1 \mathrm{r}$, of the classical complement pathway. It decreases some pro- 

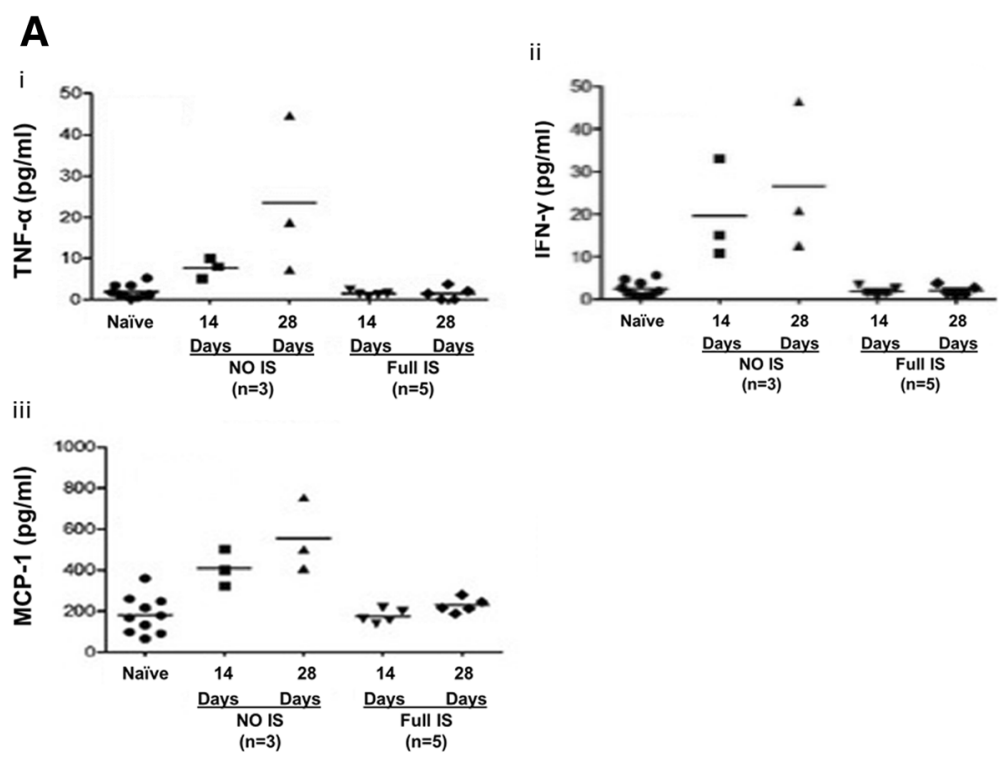

B
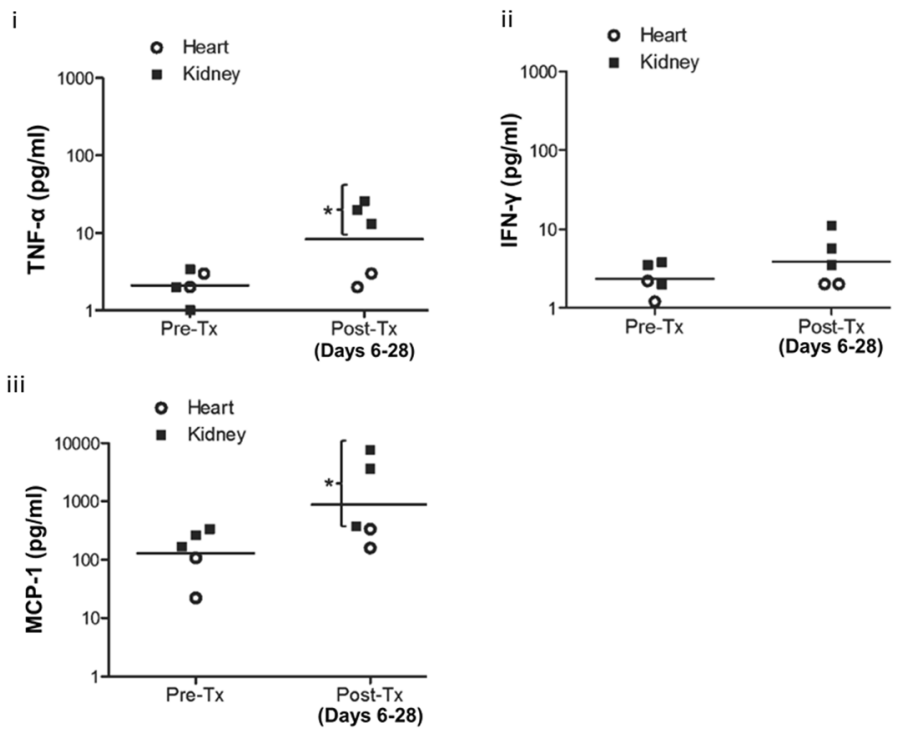

Fig. 5 a Changes in the levels of selected serum cytokines after pig-to-baboon artery patch transplantation ( $n=8$ ) (i) TNF-a; (ii) IFN-Y; (iii) MCP-1. In baboons $(n=3)$ that did not receive immunosuppressive therapy after artery patch transplantation, levels of (i) TNF-a, (ii) IFN- $\gamma$, and (iii) MCP-1 were significantly higher on post-transplant days 14 and 28 than pre-transplant. When full immunosuppressive therapy was administered to the baboons $(n=5)$, no increase in any of the three cytokines was observed. (Reprinted with permission from ref. [18]). $\mathbf{b}$ Changes in the levels of selected cytokines after pigto-baboon kidney $(n=3)$ or heart $(n=2)$ transplantation. (i) TNF-a; (ii) IFN- $\gamma$; (iii) MCP-1. Although the numbers of experiments were small, (i) TNF-a and (iii) MCP-1 were significantly higher in kidney recipients ( ${ }^{*} \mathrm{P}<0.05$ ), but not in heart recipients. (ii) IFN- $\gamma$ was not significantly increased in recipients after kidney or heart transplantation. (Reprinted with permission from ref. [18])

inflammatory cytokines (TNF- $\alpha$, IL-18) and increases a protective cytokine (IL-10) $[128,129]$.

\section{IL-6 receptor blockade, and IL-6 inhibitors}

Treatment of the NHP recipient of a pig xenograft with the IL-6 receptor blockade agent, tocilizumab, results in greatly decreased levels of C-RP (Fig. 1a) [19] and serum histones (Fig. 3a) [26]. However, D-dimer remained elevated (Fig. 4) [13, 19]. Blockade of IL-6 receptors is also associated with more rapid recovery of the fall in the level of fT3 seen after xenotransplantation (Fig. 6) [26].

Tocilizumab has several other beneficial effects on the immune response to a graft. It reduces the number of memory B cells [130,131]) and plasma cells [132], but increases regulatory B cells [133], and the ratio of regulatory $\mathrm{T}$ cells [134]. It also reduces monocytes and myeloid dendritic cells [135]. 


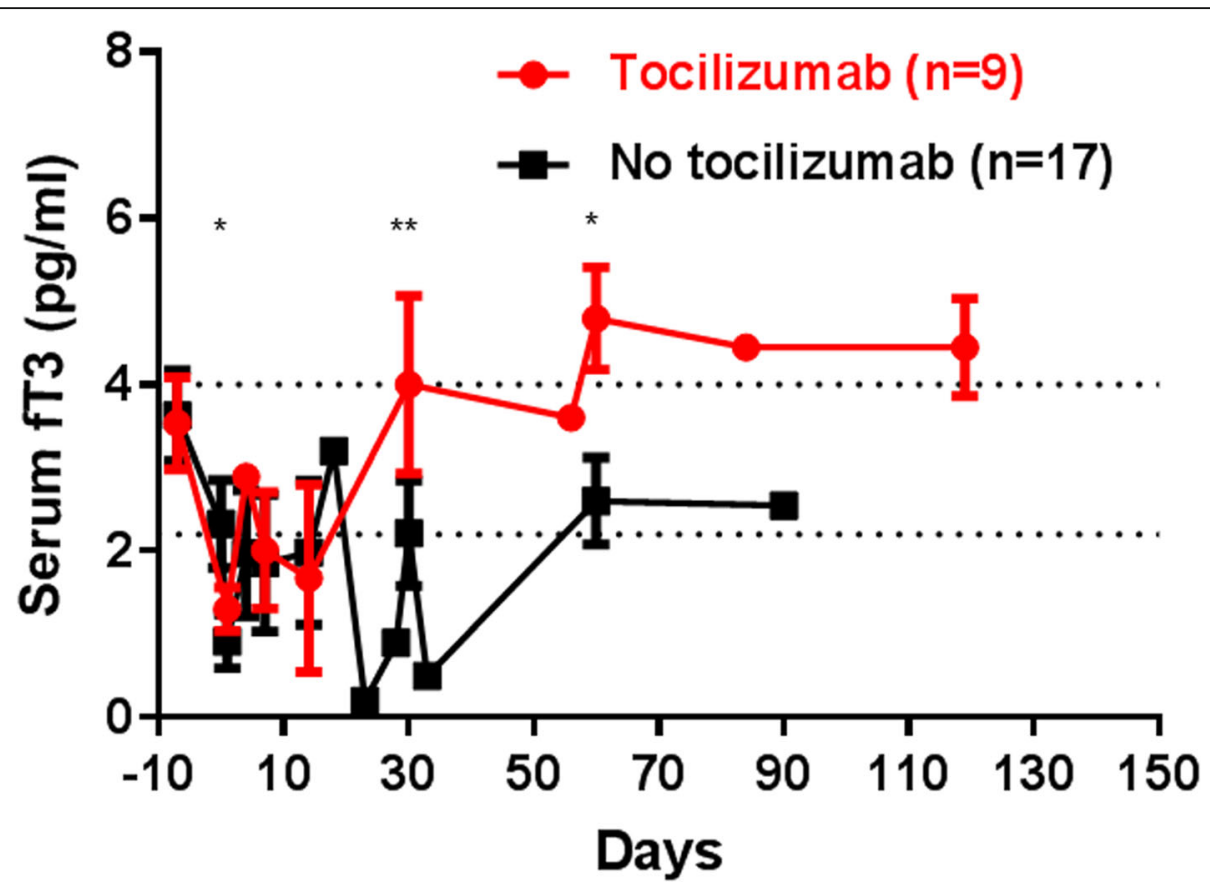

Fig. 6 Changes in serum free triiodothyronine (fT3) after pig-to-baboon organ or artery patch transplantation $(n=26)$. The serum fT3 showed an immediate and significant decrease $(P<0.001)$ in all baboons $(n=26)$ after pig organ transplantation. In baboons that received the IL-6R blocker, tocilizumab $(n=9)$, the fT3 recovered more rapidly and to a higher level than in baboons that did not receive tocilizumab ( $n=17)(\mathrm{day} 1,1.3 \mathrm{vs} 0.9 \mathrm{pg} / \mathrm{mL}$, $\mathrm{P}<0.05$; day $30,4.0$ vs $2.2 \mathrm{pg} / \mathrm{mL}, \mathrm{P}<0.01$; day $60,4.8$ vs $2.6 \mathrm{pg} / \mathrm{mL}, \mathrm{P}<0.05$, respectively). We concluded that IL-6R blockade reduced inflammation, allowing the fT3 to recover more rapidly. (Reprinted with permission from ref. [26])

Recipients of kidney allografts treated with tocilizumab suffer less antibody-mediated rejection [136], and have reduced donor-specific antibody levels [137].

However, recent evidence indicates that tocilizumab, although binding to primate IL-6 receptors, does not bind to IL-6 receptors on the pig graft [70], and therefore may have no protective effect on the graft. The IL-6 inhibitor, siltuximab, has a therapeutic effect in Castleman disease and certain inflammatory diseases by neutralizing IL-6 production [138]. IL-6 neutralization with siltuximab resulted in sustained C-RP suppression in Castleman disease [112], but it is not completely effective in xenotransplantation [Zhang G, et al., manuscript in preparation].

\section{Anti-histone antibodies}

Extracellular histones and TLR pathways are major targets for treating a variety of inflammatory conditions. Anti-histone therapy has the potential to prevent histone-induced inflammation in xenotransplantation [26]. The administration of an anti-histone antibody (e.g., anti-histone $\mathrm{H} 4$ monoclonal antibody) inhibits cytokine production and has a protective effect on various inflammatory injuries $[45,56,139-147]$. The protective effects of rTBM against histone toxicity are mediated through both activated protein $\mathrm{C}$-dependent and -independent ways [148]. Anti-histone antibodies have not yet been tested in in vivo models of xenotransplantation.

\section{TNF- $a$ inhibitors}

EC activation is reduced by a TNF- $\alpha$ inhibitor [113]. A TNF-receptor fusion protein (TNF-RFP) has reduced inflammation in an in vivo xenoperfusion model, although the mechanism of its function is poorly understood [113].

\section{NF-KB inhibitors}

NF- $k B$ plays a crucial role in enhancing the cellular responses to inflammation. Thrombin not only activates NF-кB, but also upregulates NF-кB-dependent genes [87]. As extracellular histones induce expression of tissue factor on ECs potentially through the NF- $\mathrm{kB}$ pathway, this amplifies thrombin generation [149]. The NF- $\mathrm{B}$ inhibitor, parthenolide, reduced porcine EC apoptosis/death in vitro [26] (Fig. 3b). Parthenolide has also been reported to reduce endotoxic shock and prevent inflammation in immune glomerulonephritis [150]. It is used as prophylactic treatment for migraine, and has been reported to have a beneficial effect in clinical trials [151].

\section{Alpha 1-antitrypsin (AAT)}

AAT, a prototypic serine protease inhibitor, is abundant in human blood. Although mainly produced by hepatocytes [152], it is also produced by other cells (e.g., epithelial cells [153], monocytes [154], macrophages and neutrophils [155, 156], intestinal epithelial cells [157], alpha and delta cells of human pancreatic islets [158], 

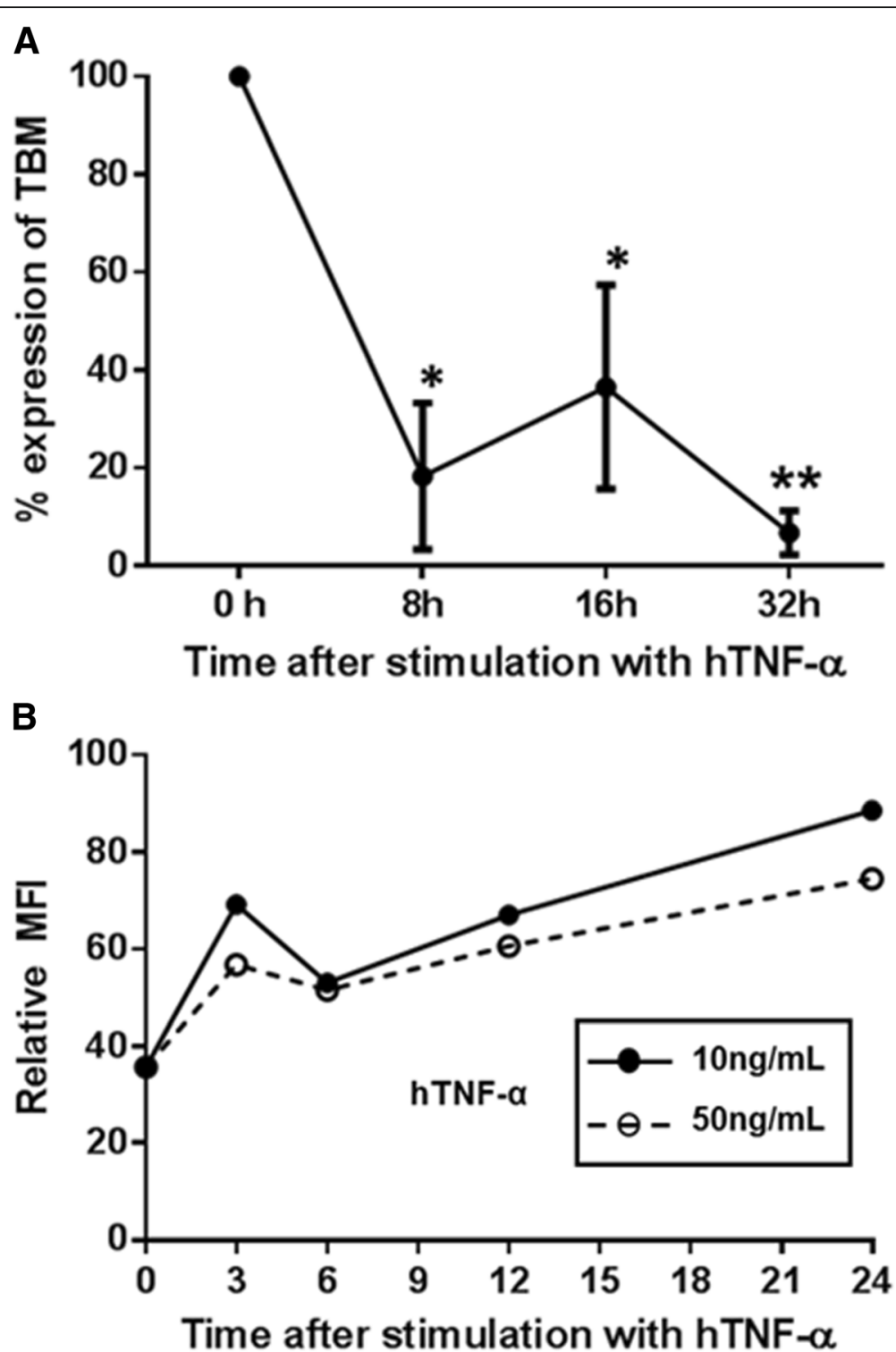

Fig. 7 a Inflammation down-regulated expression of natural pig thrombomodulin (TBM) Expression of natural pig thrombomodulin was down-regulated after exposure to TNF-a, and was confirmed by real-time PCR ( ${ }^{*} \mathrm{P}<0.05$, $\left.{ }^{*} \mathrm{P}<0.01\right)$. (The expression of pig thrombomodulin in GTKO/CD46 pig aortic endothelial cells [pAECs] was measured by real-time PCR. The PCR primer sequences used were: pTBM: Sense 5'- GAA GCT ATG AGG TCC AGC CC - 3'; Antisense 5'- CAG ACA GAC AGC GAA GAG CA - 3'.) (Details in ref. [104]). b Inflammation did not down-regulate expression of transgenic human TBM. The expression of transgenic human thrombomodulin was upregulated, confirmed by flow cytometry. Transgenically-expressed human thrombomodulin would appear to be resistant to down-regulation by inflammation. (The expression of human thrombomodulin in human thrombomodulin-transgenic pAECs was measured by flow cytometry (clone 1A4, BD Biosciences, San Jose, CA)

and cancer cells [159]). Plasma levels of AAT increase during inflammation and infection [160].

AAT has anti-inflammatory, anti-leukocyte migratory, anti-apoptotic, and anti-thrombotic effects [161166]. Treatment with AAT significantly decreases the levels of pro-inflammatory cytokines (IL-8, IL-1 $\beta$, TNF- $\alpha$ ) [115]. In monkeys with islet allotransplants, AAT prevented an inflammatory response [167] but, when baboons received artery patch grafts from genetically-engineered pigs, treatment with AAT had no effect on IL-8 and C-RP levels [13].

\section{Platelet inhibitors}

Aspirin is widely used as a preventative against vascular disease, and is associated with a reduction in myocardial infarction and stroke [168]. In addition, there is evidence that aspirin down-regulates some proinflammatory cytokines (e.g., IL-6) [116] and 


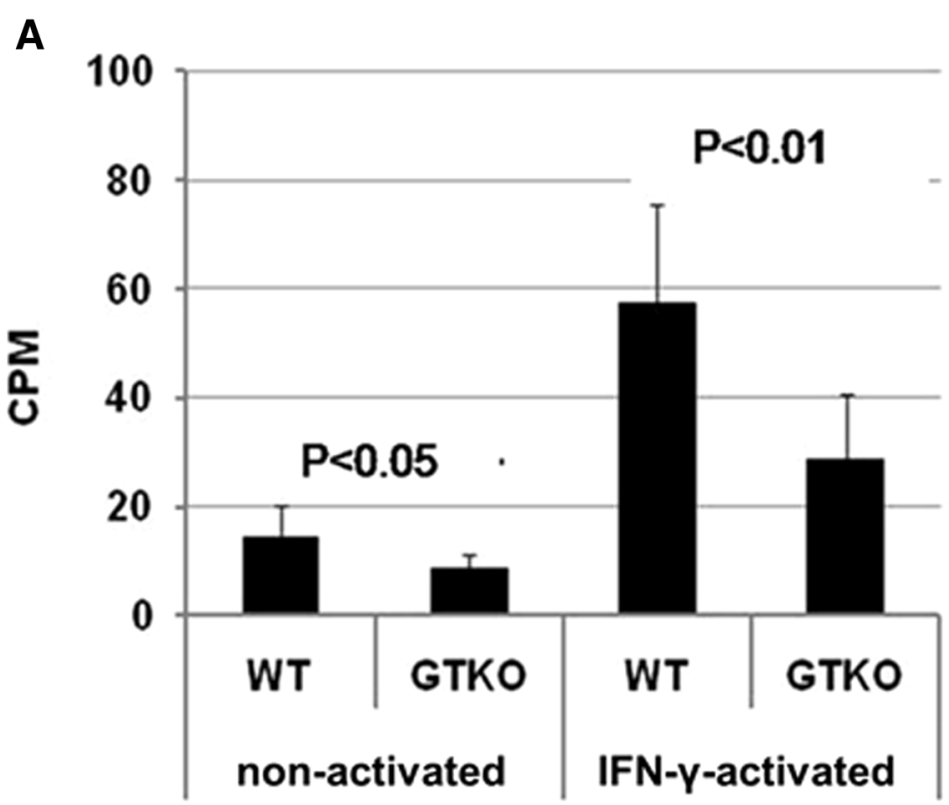

B

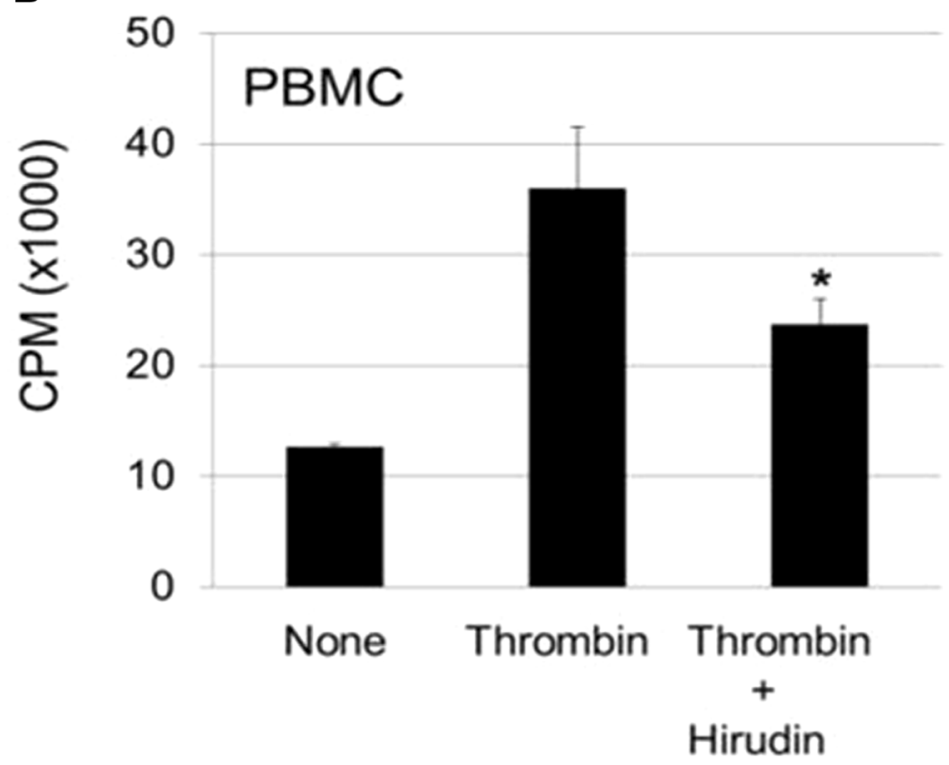

Fig. 8 a IFN- $\gamma$-activation increases the proliferative response of human peripheral blood mononuclear cells (PBMCs) to wild-type (WT) and GTKO pig aortic endothelial cells (pAECs). When non-activated, the proliferative response to WT pAECs was greater than to GTKO pAECs $(P<0.05)$. There was an increase in the PBMC response when the PAECs were activated by IFN- - , the response to WT PAECs again being significantly greater than to GTKO pAECS $(\mathrm{P}<0.01)$. The study illustrates how inflammation can increase the immune response to a xenograft. (CPM = counts per minute; $\mathrm{SI}=$ stimulation index). (Reproduced with permission from ref. [106]). b Thrombin activates T cell proliferation. The degree of activation of GTKO pig PBMCs by thrombin was comparable to that resulting from stimulation of the cells by porcine interferon-gamma (pIFN- $\gamma$ ). Thrombin-stimulated activation of the human cellular response was reduced by the addition of hirudin, confirming that thrombin was the stimulatory factor. (Reproduced with permission from ref. [97])

proinflammatory signaling pathways, including NF-kB [169-171].

\section{Triiodothyronine (T3)}

It remains uncertain whether, in the presence of a pig xenograft, the administration of $\mathrm{T}_{3}$ can suppress the inflammatory state [79], but T3 treatment reduces inflammatory cytokines (e.g., TNF- $\alpha$, IL-6), improving glycemic control in diabetic rats [119]. Nevertheless, as there is a fall in fT3 in all baboons following pig organ transplantation [30], we have found it beneficial to administer T3 to increase fT3 levels. 
Table 2 Anti-inflammatory agents that may prevent or reduce SIXR

\begin{tabular}{|c|c|c|c|}
\hline Agent & Results of therapy & & References \\
\hline Anti-complement agents & $\|\mathrm{L}-6,\| \mathrm{L}-8, \mathrm{MCP}-1$ & $\downarrow$ & [13] \\
\hline \multirow[t]{2}{*}{ IL-6 receptor blockade } & fT3, IL-6, MCP-1 & $\uparrow$ & {$[6,13,19,26,30]$} \\
\hline & Histones, C-RP, SAA & $\downarrow$ & {$[19,26]$} \\
\hline IL-6 inhibitor & C-RP & $\downarrow$ & [112] \\
\hline TNF-a inhibitor & E-selectin, VCAM-1 & $\downarrow$ & [113] \\
\hline $\begin{array}{l}\text { NF-kB inhibitor } \\
\text { (parthenolide) }\end{array}$ & Platelet aggregation, endothelial cell apoptosis & $\downarrow$ & {$[26,114]$} \\
\hline Alpha-1 antitrypsin (AAT) & IL-8, IL-1 $\beta$, TNF- $\alpha$ & $\downarrow$ & [115] \\
\hline Platelet inhibitor (aspirin) & IL-6 & $\downarrow$ & [116] \\
\hline \multirow[t]{3}{*}{$\mathrm{T}_{3}$} & Adenosine phosphate, creatine phosphate, lactate & $\downarrow$ & {$[88,117,118]$} \\
\hline & Glycogen & $\uparrow$ & \\
\hline & TNF-a, IL-6 & $\downarrow$ & [119] \\
\hline
\end{tabular}

\section{Genetic modification of the organ-source pig (Table 3)}

\section{Expression of hemeoxygenase-1 (HO-1)}

HO-1 is known to have an anti-inflammatory effect and reduces cell apoptosis $[14,172-178]$. It is an anti-oxidant enzyme, which is regulated by the erythroid 2-related factor 2 (Nrf2) pathway [194]. The activation of HO- 1 can prevent TNF- $\alpha$-induced inflammatory and oxidative damage by up-regulating the Nrf2/HO-1 signaling pathway [195]. hHO-1 expression on porcine cells prevents TNF $\alpha$ - and cycloheximide-mediated apoptosis (Fig. 9) [173-176], and results in the downregulation of adhesion molecules, e.g., E-selectin, ICAM-1, and VCAM-1 [175]. Organs expressing hHO-1 were shown to be critical for prolonged survival of mouse cardiac xenografts in rats $[173,177]$, and expression of hHO-1 in pig islets prolonged their survival in mice, and decreased immune cell infiltration and islet cell apoptosis [178].

\section{Expression of $A 20$}

A20, a TNF- $\alpha$-induced protein, has been shown to be anti-inflammatory and anti-apoptotic [179-181]. A20 is an important regulator of inflammatory signaling, which counteracts NF- $\mathrm{B}$ activation. Several reports suggested that A20 plays a crucial role in inhibiting NF- $\mathrm{kB}$ signaling in response to TNF- $\alpha$ and microbial products $[180,181]$. pAECs from hA20 transgenic pigs underwent significantly reduced apoptosis compared to wild-type pAECs [179]. hA20-transgenic pig hearts were partially protected against ischemia/reperfusion injury [179].

\section{Expression of coagulation-regulatory proteins}

Several coagulation-regulatory proteins have anti-inflammatory properties, e.g., thrombomodulin [182-187], endothelial protein C receptor (EPCR) [188], ectonucleoside triphosphate diphosphohydrolase-1 (CD39) [189-191], and tissue factor pathway inhibitor (TFPI) [192, 193]. The N-terminal lectin-like domain of thrombomodulin was reported to possess direct anti-inflammatory activity and to suppress complement activation [182]. Thrombomodulin also has anti-inflammatory effects through its capacity to promote generation of activated protein C [183-186], which exerts anticoagulant activity and has a direct cytoprotective effect [196]. Endothelial protein C receptor also

Table 3 Genetic modifications of the organ-source pig that may be protective against the inflammatory response

\begin{tabular}{|c|c|c|}
\hline Genes & Function & References \\
\hline Hemeoxygenase-1 (HO-1) & $\begin{array}{l}\text { anti-inflammatory, } \\
\text { anti-apoptotic }\end{array}$ & {$[14,172-178]$} \\
\hline A20 (tumor necrosis factor-a-induced protein) & $\begin{array}{l}\text { anti-inflammatory, } \\
\text { anti-apoptotic }\end{array}$ & {$[179-181]$} \\
\hline Thrombomodulin (TBM) & $\begin{array}{l}\text { anticoagulation, } \\
\text { anti-inflammatory }\end{array}$ & [182-187] \\
\hline Endothelial protein C receptor (EPCR) & $\begin{array}{l}\text { anticoagulation, } \\
\text { anti-inflammatory }\end{array}$ & [188] \\
\hline Ectonucleoside triphosphate diphosphohydrolase-1 (CD39) & $\begin{array}{l}\text { anticoagulation, } \\
\text { anti-inflammatory }\end{array}$ & {$[189-191]$} \\
\hline Tissue factor pathway inhibitor (TFPI) & $\begin{array}{l}\text { anticoagulation, } \\
\text { anti-inflammatory }\end{array}$ & {$[192,193]$} \\
\hline
\end{tabular}




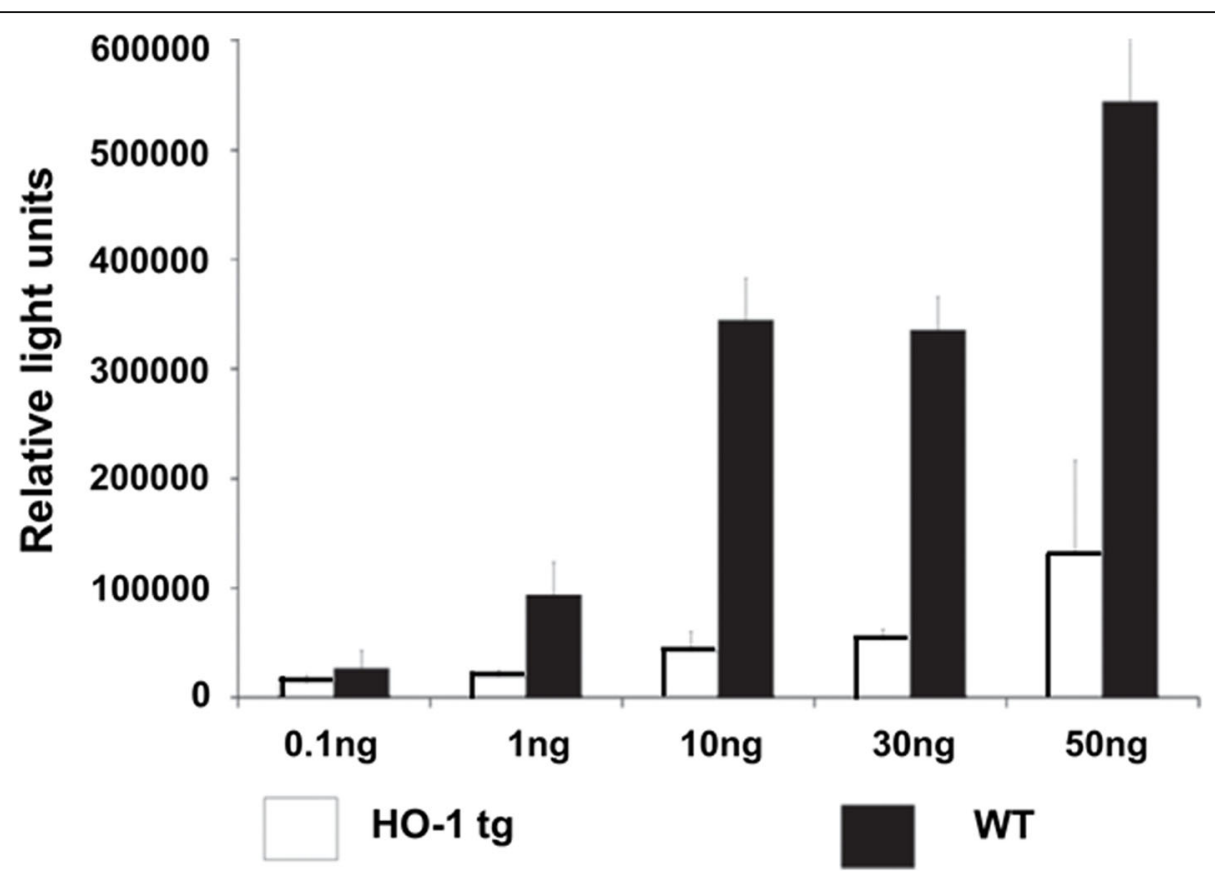

Fig. 9 TNF-a-induced apoptosis was reduced by transgenic expression of hHO-1. Human hemeoxygenase-1 (hHO-1) transgenic pig aortic endothelial cells (pAECs) were protected against TNF-a-mediated apoptosis, measured by a caspase 3/7 assay. PAECs from hHO-1 transgenic pigs were better protected against TNF-a-mediated apoptosis compared to WT pAECs. (Modified from ref. [175])

elicits activated protein C-dependent and -independent anti-inflammatory effects [188]. CD39 is a major vascular nucleoside triphosphate diphosphohydrolase, and converts adenosine triphosphate (ATP), and adenosine diphosphate (ADP) to adenosine. CD39 was demonstrated to protect kidney grafts from ischemia-reperfusion injury via anti-inflammatory adenosine receptor signaling [189], and to protect islets from the instant blood-mediated inflammatory reaction (IBMIR) [190]. TFPI is an essential anticoagulant protein that acts by preventing the activation of the blood coagulation proteases, factor VII to VIIa (fVIIa) and factor X to Xa (fXa) [197]. In murine pneumococcal pneumonia, recombinant human TFPI reduces IL-6, TNF- $\alpha$, MCP-1, IFN- $\gamma$, keratinocyte-derived cytokine, and macrophage-inflammatory protein-2, and increases the anti-inflammatory cytokine IL-10 [192].

\section{Conclusions}

Systemic inflammation may be playing a crucial role in pig organ xenotransplantation through activating the coagulation cascade and immune response. The administration of anti-inflammatory agents or the genetic modification of the organ-source pig by the introduction of human inflammation-regulatory transgenes may be beneficial to prevent or control inflammation. Control of inflammation is likely to allow a reduction in the intensity of exogenous immunosuppressive therapy. If immunological tolerance to a xenograft is to be obtained, then control of inflammation may be essential.

\section{Abbreviations}

AAT: Alpha 1-antitrypsin; C-RP: C-reactive protein; EC: Endothelial cell; $\mathrm{fT}_{3}$ : Free triiodothyronine; HO-1: Hemeoxygenase-1; IL: Interleukin; MCP1: Monocyte chemotactic protein-1; NF-kB: Nuclear factor kappa B; NHP: Nonhuman primate; SAA: Serum amyloid A; SIXR: Systemic inflammation in xenograft recipients; TFPI: Tissue factor pathway inhibitor; TLR: Toll-like receptor; TNF-a: Tumor necrosis factor-alpha

\section{Acknowledgements}

Not applicable.

Funding

Work on xenotransplantation at the University of Alabama at Birmingham is supported in part by NIH NIAID U19 grant Al090959 and by a grant from United Therapeutics, Silver Spring, MD, USA.

Availability of data and materials Not applicable.

\section{Authors' contributions}

All authors were involved in drafting and editing, they all read and approved the final manuscript.

Ethics approval and consent to participate Not applicable.

\section{Consent for publication \\ Not applicable.}

\section{Competing interests}

The authors declare that they have no competing interests.

\section{Publisher's Note}

Springer Nature remains neutral with regard to jurisdictional claims in published maps and institutional affiliations. 


\section{Author details}

'Second Affiliated Hospital, University of South China, Hengyang City, Hunan, China. ${ }^{2}$ Xenotransplantation Program, Department of Surgery, University of Alabama at Birmingham, Birmingham, AL, USA. ${ }^{3}$ Coagulation Biology Laboratory, Oklahoma Medical Research Foundation, Oklahoma City, OK, USA.

Received: 21 February 2019 Accepted: 2 May 2019

Published online: 28 May 2019

\section{References}

1. UNOS. https://unos.org/data/transplant-trends/ Accessed April 22, 2019.

2. Cooper DKC, Gollackner B, Sachs DH. Will the pig solve the transplantation backlog? Annu Rev Med. 2002:53:133-47.

3. Cooper DKC, Ezzelarab MB, Hara H, et al. The pathobiology of pig-to-primate xenotransplantation: a historical review. Xenotransplantation. 2016;23:83-105.

4. Lambrigts D, Sachs DH, Cooper DKC. Discordant organ xenotransplantation in primates - world experience and current status. Transplantation. 1998;66:547-61.

5. Iwase $\mathrm{H}$, Liu H, Wijkstrom $\mathrm{M}$, et al. Pig kidney graft survival in a baboon for 136 days: longest life-supporting organ graft survival to date. Xenotransplantation. 2015;22:302-9.

6. Iwase $\mathrm{H}$, Hara H, Ezzelarab M, et al. Immunological and physiological observations in baboons with life-supporting genetically engineered pig kidney grafts. Xenotransplantation. 2017;24. https://doi.org/10.1111/xen.12293.

7. Higginbotham L, Mathews D, Breeden CA, et al. Pre-transplant antibody screening and anti-CD154 costimulation blockade promote long-term xenograft survival in a pig-to-primate kidney transplant model. Xenotransplantation. 2015;22:221-30.

8. Adams AB, Kim SC, Martens GR, et al. Xenoantigen deletion and chemical immunosuppression can prolong renal xenograft survival. Ann Surg. 2018; 268(4):564-73.

9. Langin M, Mayr T, Reichart B, et al. Consistent success in life-supporting porcine cardiac xenotransplantation. Nature. 2018;564(7736):430-3.

10. Ghighi M, Llorens A, Baroukh B, et al. Differences between inflammatory and catabolic mediators of peri-implantitis and periodontitis lesions following initial mechanical therapy: An exploratory study. J Periodontal Res. 2018;53:29-39.

11. Sato K, Meng F, Venter J, et al. The role of the secretin/secretin receptor axis in inflammatory cholangiocyte communication via extracellular vesicles. Sci Rep. 2017;7:11183.

12. Pant S, Deshmukh A, Gurumurthy GS, et al. Inflammation and atherosclerosis--revisited. J Cardiovasc Pharmacol Ther. 2014;19:170-8.

13. Iwase H, Liu H, Li T, et al. Therapeutic regulation of systemic inflammation in xenograft recipients. Xenotransplantation. 2017;24. https://doi.org/10. 1111/xen.12296.

14. Nakamura K, Zhang M, Kageyama S, et al. Macrophage heme oxygenase-1SIRT1-p53 axis regulates sterile inflammation in liver ischemia-reperfusion injury. J Hepatol. 2017;67:1232-42.

15. Solhjou Z, Athar $H, X u$ Q, et al. Emerging therapies targeting intra-organ inflammation in transplantation. Am J Transplant. 2015;15:305-11.

16. Labarrere CA, Woods JR, Hardin JW, et al. Early inflammatory markers are independent predictors of cardiac allograft vasculopathy in heart-transplant recipients. PLoS One. 2014;9(12):e113260.

17. Ezzelarab MB, Cooper DK. Systemic inflammation in xenograft recipients (SIXR): a new paradigm in pig-to-primate xenotransplantation? Int J Surg. 2015;23:301-5.

18. Ezzelarab MB, Ekser B, Azimzadeh A, et al. Systemic inflammation in xenograft recipients precedes activation of coagulation. Xenotransplantation. 2015;22:32-47.

19. Iwase $H$, Ekser $B$, Zhou $H$, et al. Further evidence for a sustained systemic inflammatory response in xenograft recipients (SIXR). Xenotransplantation. 2015;22:399-405

20. Strukova S. Coagulation-dependent inflammation and inflammationdependent thrombosis. Front Biosci. 2006;11:59-80.

21. Iwase $\mathrm{H}$, Ekser $\mathrm{B}$, Zhou $\mathrm{H}$, et al. Platelet aggregation in humans and nonhuman primates: relevance to xenotransplantation. Xenotransplantation. 2012;19:233-43.

22. Ezzelarab $M$, Welchons $D$, Torres $C$, et al. Atorvastatin down-regulates the primate cellular response to porcine aortic endothelial cells in vitro. Transplantation. 2008;86:733-7.

23. Xu J, Lupu F, Esmon CT, et al. Inflammation, innate immunity and blood coagulation. Hamostaseologie. 2010;30:5-6, 8-9.
24. Ezzelarab M, Garcia B, Azimzadeh A, et al. The innate immune response and activation of coagulation in alpha1, 3-galactosyltransferase gene-knockout xenograft recipients. Transplantation. 2009;87:805-12.

25. Chong AS, Alegre ML. The impact of infection and tissue damage in solidorgan transplantation. Nat Rev Immunol. 2012;12:459-71.

26. Li T, Lee $\mathrm{W}$, Hara $\mathrm{H}$, et al. An investigation of extracellular histone in pig-tobaboon organ xenotransplantation. Transplantation. 2017;101:2330-9.

27. Li $\mathrm{T}$, Iwase $\mathrm{H}$, Hara $\mathrm{H}$, Long $\mathrm{C}$, et al. Serum amyloid a as a marker of inflammation in xenotransplantation. Eur J Inflamm. 2018. https://doi.org/10. $1177 / 2058739218780046$

28. Zhang G, Hara H, Yamamoto $T$, et al. Serum amyloid a as an indicator of impending xenograft failure: experimental studies. Int J Surg. 2018. https:// doi.org/10.1016/j.ijsu.2018.11.027.

29. Ezzelarab MB, Ekser B, Isse K, et al. Increased soluble CD154 (CD40 ligand) levels in xenograft recipients correlate with the development of de novo anti-pig lgG antibodies. Transplantation. 2014;97:502-8.

30. Iwase H, Ekser B, Hara H, et al. Thyroid hormone: relevance to xenotransplantation. Xenotransplantation. 2016;23:293-9.

31. An HJ, Jang JW, Bae SH, et al. Serum C-reactive protein is a useful biomarker for predicting outcomes after liver transplantation in patients with hepatocellular carcinoma. Liver Transpl. 2012;18:1406-14.

32. Ansar W, Ghosh S. C-reactive protein and the biology of disease. Immunol Res. 2013;56:131-42.

33. Neumaier M, Braun KF, Sandmann G, et al. C- reactive protein in orthopaedic surgery. Acta Chir Orthop Traumatol Cechoslov. 2015;82:327-31.

34. Jabs WJ, Lögering BA, Gerke $P$, et al. The kidney as a second site of human C-reactive protein formation in vivo. Eur J Immunol. 2003;33:152-61.

35. Urieli-Shoval S, Linke RP, Matzner Y. Expression and function of serum amyloid a, a major acute-phase protein, in normal and disease states. Curr Opin Hematol. 2000;7:64-9.

36. Ye RD, Sun L. Emerging functions of serum amyloid a in inflammation. J Leukoc Biol. 2015;98:923-9.

37. Hartmann A, Eide TC, Fauchald P, et al. Serum amyloid a protein is a clinically useful indicator of acute renal allograft rejection. Nephrol Dial Transplant. 1997;12:161-6.

38. Eklund KK, Niemi K, Kovanen PT, et al. Immune functions of serum amyloid a. Crit Rev Immunol. 2012;32:335-48.

39. Dong Z, Wu T, Qin W, et al. Serum amyloid a directly accelerates the progression of atherosclerosis in apolipoprotein E-deficient mice. Mol Med. 2011;17:1357-64.

40. Uhlar CM, Whitehead AS. Serum amyloid a, the major vertebrate acutephase reactant. Eur J Biochem. 1999;265:501-23.

41. Furlaneto CJ, Campa A. A novel function of serum amyloid a: a potent stimulus for the release of tumor necrosis factor-alpha, interleukin-1beta, and interleukin- 8 by human blood neutrophil. Biochem Biophys Res Commun. 2000;268:405-8.

42. Ribeiro FP, Furlaneto CJ, Hatanaka $E$, et al. mRNA expression and release of interleukin-8 induced by serum amyloid a in neutrophils and monocytes. Mediat Inflamm. 2003;12:173-8.

43. De Buck M, Gouwy M, Wang JM, et al. The cytokine-serum amyloid Achemokine network. Cytokine Growth Factor Rev. 2016;30:55-69.

44. Kisilevsky R, Manley PN. Acute-phase serum amyloid a: perspectives on its physiological and pathological roles. Amyloid. 2012;19:5-14.

45. Xu J, Zhang $X$, Pelayo R, et al. Extracellular histones are major mediators of death in sepsis. Nat Med. 2009:15:1318-21.

46. Finch JT, Lutter LC, Rhodes D, et al. Structure of nucleosome core particles of chromatin. Nature. 1977:269:29-36.

47. Luger K, Mäder AW, Richmond RK, et al. Crystal structure of the nucleosome core particle at 2.8 a resolution. Nature. 1997:389:251-60.

48. Esmon CT. Molecular circuits in thrombosis and inflammation. Thromb Haemost. 2013:109:416-20.

49. Semeraro F, Ammollo $\subset$, Esmon NL, et al. Histones induce phosphatidylserine exposure and a procoagulant phenotype in human red blood cells. J Thromb Haemost. 2014;12:1697-702.

50. Esmon CT, Xu J, Lupu F. Innate immunity and coagulation. J Thromb Haemost. 2011;9:182-8.

51. Fuchs TA, Bhandari AA, Wagner DD, et al. Histones induce rapid and profound thrombocytopenia in mice. Blood. 2011;118:3708-14.

52. Etulain J, Martinod K, Wong SL, et al. P-selectin promotes neutrophil extracellular trap formation in mice. Blood. 2015;126:242-6. 
53. Semeraro F, Ammollo $C T$, Morrissey JH, et al. Extracellular histones promote thrombin generation through platelet-dependent mechanisms: involvement of platelet TLR2 and TLR4. Blood. 2011;118:1952-61.

54. Xu J, Zhang $X$, Monestier $M$, et al. Extracellular histones are mediators of death through TLR2 and TLR4 in mouse fatal liver injury. J Immunol. 2011; 187:2626-31.

55. Bosmann M, Grailer JJ, Ruemmler R, et al. Extracellular histones are essential effectors of C5aR- and C5L2-mediated tissue damage and inflammation in acute lung injury. FASEB J. 2013;27:5010-21.

56. Allam R, Darisipudi MN, Tschopp J, et al. Histones trigger sterile inflammation by activating the NLRP3 inflammasome. Eur J Immunol. 2013;43:3336-42.

57. Allam R, Santhosh V. Extracellular histones in tissue injury and inflammation. J Mol Med. 2014;92:465-72.

58. Esmon CT. Extracellular histones zap platelets. Blood. 2011;118:3456-7.

59. Ogata A, Hirano T, Hishitani Y, et al. Safety and efficacy of tocilizumab for the treatment of rheumatoid arthritis. Clin Med Insights Arthritis Musculoskelet Disord. 2012;5:27-42.

60. Tanaka T, Narazaki M, Kishimoto T, et al. Anti-interleukin-6 receptor antibody, tocilizumab, for the treatment of autoimmune diseases. FEBS Lett. 2011;585:3699-709.

61. Winn RK, Harlan JM. The role of endothelial cell apoptosis in inflammatory and immune diseases. J Thromb Haemost. 2005;3:1815-24.

62. Shorr AF, Thomas SJ, Alkins SA, et al. D-dimer correlates with proinflammatory cytokine levels and outcomes in critically ill patients. Chest. 2002;121:1262-8

63. Edgington TS, Curtiss LK, Plow EF, et al. A linkage between the haemostatic and immune systems embodied in the fibrinolytic release of lymphocytic suppressive peptides. J Immunol. 1985;134:471-7.

64. Robson SC, Shephard EG, Kirsch RE, et al. Fibrin degradation product Ddimer induces the synthesis and release of biologically active IL-1 beta, IL-6 and plasminogen activator inhibitors from monocytes in vitro. $\mathrm{Br} J$ Haematol. 1994:86:322-6.

65. Rao KMK, Pieper CS, Currie MS, et al. Variability of plasma IL-6 and crosslinked fibrin D-dimer over time in community dwelling elderly subjects. Am J Clin Pathol. 1994;102:802-5.

66. Bao W, Qi X, Li H, et al. Correlation of D-dimer level with the inflammatory conditions: a retrospective study. AME Med J. 2017;2:1-8.

67. Zhang J, Guo Z, Yang W, et al. D-dimer levels are correlated with disease activity in Crohn's patients. Oncotarget. 2017:8:63971-7.

68. Ulloa L, Tracey KJ. The "cytokine profile": a code for sepsis. Trends Mol Med. 2005;11:56-63.

69. Wilson N, Djamali A, Redfield R. Elevation of peripheral IL-6 in kidney transplant recipients with antibody mediated rejection. Am J Transplant. 2016:16:707 Abstract) (D32).

70. Gao H, Liu L, Zhao Y, et al. Human IL-6, IL-17, IL-1 $\beta$, and TNF-a differently regulate the expression of pro-inflammatory related genes, tissue factor, and swine leukocyte antigen class I inporcineaortic endothelial cells Xenotransplantation. 2017;24(2). https://doi.org/10.1111/xen.12291.

71. Wagner DD, Burger PC. Platelets in inflammation and thrombosis. Arterioscler Thromb Vasc Biol. 2003;23:2131-7.

72. Lin CC, Ezzelarab M, Shapiro R, et al. Recipient tissue factor expression is associated with consumptive coagulopathy in pig-to-primate kidney xenotransplantation. Am J Transplant. 2010;10:1556-68.

73. Maione F, Cicala C, Liverani E, et al. IL-17A increases ADP-induced platelet aggregation. Bioc Biop Res Commun. 2011;408:658-62.

74. Zhang S, Yuan J, Yu M, et al. IL-17A facilitates platelet function through the ERK2 signaling pathway in patients with acute coronary syndrome. PLoS One. 2012;7(7):e40641. https://doi.org/10.1371/journal.pone.0040641.

75. Jing $Y$, Peiwu D, Miao $Y$, et al. IL-17 induces MPTP opening through ERK2 and p53 signaling pathway in human platelets. J Huazhong Univ Sci Technolog Med Sci. 2015;35:679-83.

76. Bombeli T, Schwartz BR, Harlan JM, et al. Endothelial cells undergoing apoptosis become proadhesive for nonactivated platelets. Blood. 1999;93:3831-8.

77. Lin CC, Chen D, McVey JH, et al. Expression of tissue factor and initiation of clotting by human platelets and monocytes after incubation with porcine endothelial cells. Transplantation. 2008;86:702-9.

78. Zoccali C, Tripepi G, Cutrupi S, Pizzini P, Mallamaci F. Low triiodothyronine: a new facet of inflammation in end-stage renal disease. J Am Soc Nephrol. 2005;16:2789-95.

79. Novitzky D, Cooper DK. Thyroid hormone and the stunned myocardium. J Endocrinol. 2014;223:R1-8.
80. Lee $\mathrm{WY}$, Kang Ml, OH KW, et al. Relationship between circulating cytokine levels and thyroid function following bone marrow transplantation. Bone Marrow Transplant. 2004;33:93-8.

81. Paraskevaidis IA, Parissis JT, TH Kremastinos D, et al. Antiinflammatory and antiapoptotic effects of levosimendan in decompensated heart failure: a novel mechanism of drug-induced improvement in contractile performance of the failing heart. Curr Med Chem Cardiovasc Hematol Agents. 2005;3:243-7.

82. Lubrano V, Pingitore A, Carpi A, et al. Relationship between triiodothyronine and proinflammatory cytokines in chronic heart failure. Biomed Pharmacother. 2010;64:165-9.

83. Novitzky D, Wicomb WN, Cooper DKC, et al. Electrocardiographic, hemodynamic and endocrine changes occurring during experimental brain death in the Chacma baboon. J Heart Transplant. 1984:4:63-9.

84. Novitzky D, Cooper DKC, Reichart B. Hemodynamic and metabolic responses to hormonal therapy in brain-dead potential organ donors. Transplantation. 1987;43:852-4

85. Bremner WF, Taylor KM, Baird S, et al. Hypothalamo-pituitary thyroid axis function during cardiopulmomary bypass. J Thorac Cardiovasc Surg. 1978; 75:392-9.

86. Robuschi G, Medici D, Fesani F, et al. Cardiopulmonary bypass: a low T4 and T3 syndrome with blunted thyrotropinin (TSH) response to thyrotropinreleasing hormone (TRH). Horm Res. 1986;23:151-8.

87. Novitzky D, Human PA, Cooper DKC. Effect of triiodothyronine (T3) on myocardial high energy phosphates and lactate following ischemia and cardiopulmonary bypass - an experimental study in baboons. J Thorac Cardiovasc Surg. 1986;96:600-7.

88. Novitzky D, Human PA, Cooper DKC. Inotropic effect of triiodothyronine following myocardial ischaemia and cardiopulmonary bypass: an experimental study in pigs. Ann Thorac Surg. 1988;45:50-5.

89. Novitzky D, Cooper DKC, Swanepoel A. Inotropic effect of triiodothyronine (T3) following myocardial ischemia and cardiopulmonary bypass: initial experience in patients undergoing open heart surgery. Eur J Cardiothorac Surg. 1989;3:140-5.

90. Buhler $L$, Basker M, Ip A, et al. Coagulation and thrombotic disorders associated with pig organ and hematopoietic cell transplantation in nonhuman primates. Transplantation. 2000;70:1323-31.

91. Buhler $\mathrm{L}$, Yamada $\mathrm{K}$, Kitamural $\mathrm{H}$, et al. Pig kidney transplantation in baboons: anti-gal (alpha)1-3Gal lgM alone is associated with acute humoral xenograft rejection and disseminated intravascular coagulation. Transplantation. 2001;72:1743-52.

92. Cowan PJ, Aminian A, Barlow H, et al. Renal xenografts from tripletransgenic pigs are not hyperacutely rejected but cause coagulopathy in non-immunosuppressed baboons. Transplantation. 2000:69:2504-15.

93. Wang L, Cooper DKC, Burdorf L, Wang Y, Iwase H. Overcoming coagulation dysregulation in pig solid organ transplantation in nonhuman Primates: recent Progress. Transplantation. 2018;102(7):1050-8. https://doi.org/10. 1097/TP.0000000000002171.

94. Li X, Syrovets T, Paskas S, et al. Mature dendritic cells express functional thrombin receptors triggering chemotaxis and CCL18/pulmonary and activation-regulated chemokine induction. J Immunol. 2008;181:1215-23.

95. Clark P, Jordan F, Pearson C, et al. Intercellular adhesion molecule-1 (ICAM-1) expression is upregulated by thrombin in human monocytes and THP-1 cells in vitro and in pregnant subjects in vivo. Thromb Haemost. 2003;89:1043-51.

96. Anrather D, Millan MT, Palmetshofer A, et al. Thrombin activates nuclear factor-kappaB and potentiates endothelial cell activation by TNF. J Immunol. 1997;159:5620-8.

97. Ezzelarab C, Ayares D, Cooper DKC, et al. Human T-cell proliferation in response to thrombin-activated GTKO pig endothelial cells. Xenotransplantation. 2012;19:311-6.

98. Hara $\mathrm{H}$, Iwase $\mathrm{H}$, Miyagawa $\mathrm{Y}$, et al. Reducing the inflammatory response by expressimng human thrombomodulin in pigs. Xenotransplantation. 2017;24: 19-20 Abstract) (PL.3.11

99. Chu AJ. Tissue factor mediates inflammation. Arch Biochem Biophys. 2005 440:123-32

100. Chu AJ. Tissue factor, blood coagulation, and beyond: an overview. Int J Inflam. 2011;2011:367284. https://doi.org/10.4061/2011/367284.

101. Kambas K, Markiewski MM, Pneumatikos IA, et al. C5a and TNF-alpha upregulate the expression of tissue factor in intra-alveolar neutrophils of patients with the acute respiratory distress syndrome. J Immunol. 2008;180:7368-75.

102. Kruithof EK, Mestries JC, Gascon MP, et al. The coagulation and fibrinolytic responses of baboons after in vivo thrombin generation-effect of interleukin 6. Thromb Haemost. 1997;77:905-10. 
103. Wu J, Stevenson MJ, Brown JM, et al. C-reactive protein enhances tissue factor expression by vascular smooth muscle cells: mechanisms and in vivo significance. Arterioscler Thromb Vasc Biol. 2008;28:698-704.

104. Lee W, Miyagawa Y, Long C, Zhang M, Cooper DK, Hara H. Effect of rho-kinase inhibitor, Y27632, on porcine corneal endothelial cell culture, inflammation and immune regulation. Ocul Immunol Inflamm. 2016;24:579-93.

105. Pankratz S, Bittner S, Herrmann AM, et al. Human CD4+ HLA-G+ regulatory $T$ cells are potent suppressors of graft-versus-host disease in vivo. FASEB $J$. 2014:28:3435-45.

106. Wilhite T, Ezzelarab C, Hara $\mathrm{H}$, et al. The effect of gal expression on pig cells on the human T-cell xenoresponse. Xenotransplantation. 2012;19:56-63.

107. Kim N, Yoon Yl, Yoo HJ, et al. Combined detection of serum IL-10, IL-17, and CXCL10 predicts acute rejection following adult liver transplantation. Mol Cells. 2016;39:639-44.

108. Tang J, Shi Y, Deng R, et al. Cytokine profile in calcineurin inhibitor-induced chronic nephrotoxicity in Chinese liver transplant recipients. Transplant Proc 2016:48:2756-62.

109. Hoffman SA, Wang L, Shah CV, et al. Plasma cytokines and chemokines in primary graft dysfunction post-lung transplantation. Am J Transplant. 2009;9:389-96.

110. Uchida $Y$, Ke B, Freitas MC, et al. T-cell immunoglobulin mucin-3 determines severity of liver ischemia/reperfusion injury in micein a TLR4-dependent manner. Gastroenterology. 2010;139:2195-206.

111. Oweira H, Lahdou I, Daniel V, et al. Early post-operative acute phase response in patients with early graft dysfunction is predictive of 6-month and 12-month mortality in liver transplant recipients. Hum Immunol. 2016; 77:952-60

112. Casper C, Chaturvedi S, Munshi N, et al. Analysis of inflammatory and anemia-related biomarkers in a randomized, double-blind, placebocontrolled study of siltuximab (anti-IL6 monoclonal antibody) in patients with multicentric castleman disease. Clin Cancer Res. 2015;21:4294-304.

113. Ramackers W, Klose J, Tiede A, et al. Effect of TNF-alpha blockade on coagulopathy and endothelial cell activation in xenoperfused porcine kidneys. Xenotransplantation. 2015;22:284-94.

114. Malaver E, Romaniuk MA, D'Atri LP, et al. NF-kappaB inhibitors impair platelet activation responses. J Thromb Haemost. 2009;7:1333-43.

115. Griese $M$, Latzin $P$, Kappler $M$, et al. Alpha1-antitrypsin inhalation reduces airway inflammation in cystic fibrosis patients. Eur Respir J. 2007:29:240-50.

116. Hovens MM, Snoep JD, Groeneveld Y, Frölich M, Tamsma JT, Huisman MV. Effects of aspirin on serum C-reactive protein and interleukin-6 levels in patients with type 2 diabetes without cardiovascular disease: a randomized placebo-controlled crossover trial. Diabetes Obes Metab. 2008;10:668-74.

117. Wicombl WN, Cooper DK, Novitzky D, et al. Impairment of renal slice function following brain death, with reversibility of injury by hormonal therapy. Transplantation. 1986;41:29-33.

118. Novitzky D, Cooper DKC. The brain-dead organ donor: pathophysiology and management. New York: Springer; 2013. p. 1-416.

119. Panveloski-Costa AC, Silva Teixeira S, Ribeiro IM, et al. Thyroid hormone reduces inflammatory cytokines improving glycaemia control in alloxaninduced diabetic wistar rats. Acta Physiol (Oxf). 2016;217:130-40.

120. Hall SE, Lim S, Witherden IR, et al. Lung type II cell and macrophage annexin I release: differential effects of two glucocorticoids. Am J Phys. 1999:276:L114-21.

121. Osipov AV, Mordvintsev DY, Starkov VG, et al. Naja melanoleuca cobra venom contains two forms of complement-depleting factor (CVF). Toxicon. 2005;46:394-403.

122. Rother RP, Rollins SA, Mojcik CF, et al. Discovery and development of the complement inhibitor eculizumab for the treatment of paroxysmal nocturnal hemoglobinuria. Nat Biotechnol. 2007;5:1256-64.

123. Longhi MP, Harris $\mathrm{CL}$, Morgan $\mathrm{BP}$, et al. Holding T cells in check-a new role for complement regulators? Trends Immunol. 2006;27:102-8.

124. Liu J, Liu T, Miwa, et al. The complement inhibitory protein DAF (CD55) suppresses T cell immunity in vivo. J Exp Med. 2005;201:567-77.

125. Heeger PS, Lalli PN, et al. Decay-accelerating factor modulates induction of T cell immunity. J Exp Med. 2005;201:1523-30.

126. Qu H, Ricklin D, Bai H, et al. New analogues of the clinical complement inhibitor compstatin with subnanomolar affinity and enhanced pharmacokinetic properties. Immunobiology. 2013;218:496-505.

127. Mastellos DC, Yancopoulou D, Kokkinos P, et al. Compstatin: a C3-targeted complement inhibitor reaching its prime for bedside intervention. Eur J Clin Investig. 2015;45:423-40.
128. Davis AE, Lu F, Mejia P, et al. C1 inhibitor, a multi-functional serine protease inhibitor. Thromb Haemost. 2010;104:886-93.

129. Kim KY, Kim MY, Choi HS, et al. Thrombin induces IL-10 production in microglia as a negative feedback regulator of TNF-alpha release. NeuroReport. 2002;13:849-52.

130. Roll $P$, Muhammad K, Schumann $M$, et al. In vivo effects of the antiinterleukin-6 receptor inhibitor tocilizumab on the B cell compartment. Arthritis Rheum. 2011;63:1255-64.

131. Muhammad K, Roll P, Seibold T, et al. Impact of IL-6 receptor inhibition on human memory B cells in vivo: impaired somatic hypermutation in preswitch memory B cells and modulation of mutational targeting in memory B cells. Ann Rheum Dis. 2011;70:1507-10.

132. Illei GG, Shirota Y, Yarboro $\mathrm{CH}$, et al. Tocilizumab in systemic lupus erythematosus: data on safety, preliminary efficacy, and impact on circulating plasma cells from an open-label phase I dosage-escalation study. Arthritis Rheum. 2010;62:542-52.

133. Snir A, Kessel A, Haj T, et al. Anti-IL-6 receptor antibody (tocilizumab): a B cell targeting therapy. Clin Exp Rheumatol. 2011;29:697-700.

134. Samson M, Audia S, Janikashvili N, et al. Inhibition of IL-6 function corrects Th17/Treg imbalance in rheumatoid arthritis patients. Arthritis Rheum. 2012; 64:2499-503.

135. Richez $C$, Barnetche $T$, Khoryati $L$, et al. Tocilizumab treatment decreases circulating myeloid dendritic cells and monocytes, 2 components of the myeloid lineage. J Rheumatol. 2012;39:1192-7.

136. Vo AA, Choi J, Kim I, et al. A phase I/II trial of the interleukin-6 receptor-specific humanized monoclonal (tocilizumab) + intravenous immunoglobulin in difficult to desensitize patients. Transplantation. 2015;99:2356-63.

137. Choi J, Aubert O, Vo A, et al. Assessment of tocilizumab (anti-Interleukin-6 receptor monoclonal) as a potential treatment for chronic antibodymediated rejection and transplant glomerulopathy in HLA-sensitized renal allograft recipients. Am J Transplant. 2017;17:2381-9.

138. Rossi JF, Lu ZY, Jourdan M, Klein B. Interleukin-6 as a therapeutic target. Clin Cancer Res. 2015;21:1248-57.

139. Kusano T, Chiang KC, Inomata M, et al. A novel anti-histone $\mathrm{H} 1$ monoclonal antibody, SSV monoclonal antibody, improves lung injury and survival in a mouse model of lipopolysaccharide-induced sepsis-like syndrome. Biomed Res Int. 2015:2015:491649.

140. Monestier M, Fasy TM, Losman MJ, et al. Structure and binding properties of monoclonal antibodies to core histones from autoimmune mice. Mol Immunol. 1993;30:1069-75.

141. Kuriyama N, Isaji S, Hamada T, et al. Activated protein C prevents hepatic ischaemia-reperfusion injury in rats. Liver Int. 2009;29:299-307.

142. Huang $\mathrm{H}$, Evankovich J, Yan W, et al. Endogenous histones function as alarmins in sterile inflammatory liver injury through toll-like receptor 9 in mice. Hepatology. 2011;54:999-1008.

143. Abrams ST, Zhang N, Manson J, et al. Circulating histones are mediators of trauma-associated lung injury. Am J Respir Crit Care Med. 2013;187:160-9.

144. Bosmann M, Ward PA. Protein based therapies for acute lung injury: targeting neutrophil extracellular traps. Expert Opin Ther Targets. 2014;18:703-14.

145. Chen R, Kang R, Fan XG, et al. Release and activity of histone in diseases. Cell Death Dis. 2014;5:e1370

146. Daigo K, Takamatsu Y, Hamakubo T, et al. The protective effect against extracellular histones afforded by long-Pentraxin PTX3 as a regulator of NETs. Front Immunol. 2016:7:1-9.

147. Wildhagen KC, García de Frutos $P$, Reutelingsperger $C P$, et al. Nonanticoagulant heparin prevents histone-mediated cytotoxicity in vitro and improves survival in sepsis. Blood. 2014;123:1098-101.

148. Nakahara M, Ito T, Kawahara K, et al. Recombinant thrombomodulin protects mice against histone-induced lethal thromboembolism. PLoS One. 2013;8:e75961.

149. Yang X, Li L, Liu J, et al. Extracellular histones induce tissue factor expression in vascular endothelial cells via TLR and activation of NF-KB and AP-1. Thromb Res. 2016;137:211-8.

150. Sheehan M, Wong HR, Hake PW, Malhotra V, O'Connor M, Zingarelli B. Parthenolide, an inhibitor of the nuclear factor-kappaB pathway, ameliorates cardiovascular derangement and outcome in endotoxic shock in rodents. Mol Pharmacol. 2002;61:953-63.

151. Dey S, Sarkar M, Giri B. Anti-inflammatory and anti-tumor activities of parthenolide: An update. J Chem Biol Ther. 2016;1(2):107. https://doi.org/10. 4172/2572-0406.1000107

152. Rogers J, Kalsheker N, Wallis S, et al. The isolation of a clone for human alpha 1-antitrypsin and the detection of alpha 1-antitrypsin in mRNA from liver and leukocytes. Biochem Biophys Res Commun. 1983;116:375-82. 
153. Cichy J, Potempa J, Travis J, et al. Biosynthesis of alpha1-proteinase inhibitor by human lung-derived epithelial cells. J Biol Chem. 1997;272:8250-5.

154. Carroll TP, Greene CM, O'Connor CA, et al. Evidence for unfolded protein response activation in monocytes from individuals with alpha- 1 antitrypsin deficiency. J Immunol. 2010;184:4538-46.

155. Bergin DA, Reeves EP, Meleady P, et al. Alpha-1 antitrypsin regulates human neutrophil chemotaxis induced by soluble immune complexes and IL-8. J Clin Invest. 2010;120:4236-50.

156. Du Bois RM, Bernaudin JF, Paakko P, et al. Human neutrophils express the alpha 1-antitrypsin gene and produce alpha 1-antitrypsin. Blood. 1991;77:2724-30.

157. Molmenti EP, Perlmutter DH, Rubin DC. Cell-specific expression of alpha 1antitrypsin in human intestinal epithelium. J Clin Invest. 1993;92:2022-34.

158. Bosco D, Meda P, Morel P, et al. Expression and secretion of alpha1proteinase inhibitor are regulated by proinflammatory cytokines in human pancreatic islet cells. Diabetologia. 2005;48:1523-33.

159. Chen XL, Zhou L, Yang J, et al. Hepatocellular carcinoma-associated protein markers investigated by MALDI-TOF MS. Mol Med Report. 2010;3:589-96.

160. Perlmutter DH. Alpha-1-antitrypsin deficiency: diagnosis and treatment. Clin Liver Dis. 2004;8:839-59.

161. Abbas AK, Corson JM, Carpenter CB, et al. Immunologic enhancement of rat renal allografts. III. Immunopathologic lesions and rejection in long-surviving passively enhanced grafts. Am J Pathol. 1975;79:255-70.

162. Churg A, Dai J, Zay K, et al. Alpha-1-antitrypsin and a broad spectrum metalloprotease inhibitor, RS113456, have similar acute anti-inflammatory effects. Lab Investig. 2001;81:1119-31.

163. Jie $Z$, Cai $Y$, Yang W, et al. Protective effects of alpha 1-antitrypsin on acute lung injury in rabbits induced by endotoxin. Chinese Med J. 2003;116:1678-82.

164. Lewis EC, Shapiro L, Bowers OJ, et al. Alpha1-antitrypsin monotherapy prolongs islet allograft survival in mice. Proc Natl Acad Sci U S A. 2005;102:12153-8.

165. Petrache I, Fijalkowska I, Zhen L, et al. A novel antiapoptotic role for alpha1antitrypsin in the prevention of pulmonary emphysema. Am J Respir Crit Care Med. 2006;173:1222-8.

166. Petrache I, Hajjar J, Campos M. Safety and efficacy of alpha-1-antitrypsin augmentation therapy in the treatment of patients with alpha-1-antitrypsin deficiency. Biologics. 2009:3:193-204.

167. Koulmanda M, Sampathkumar RS, Bhasin M, et al. Prevention of nonimmunologic loss of transplanted islets in monkeys. Am J Transplant. 2014;14:1543-51.

168. Antithrombotic Trialists' Collaboration. Collaborative meta-analysis of randomised trials of antiplatelet therapy for prevention of death, myocardial infarction, and stroke in high risk patients. BMJ. 2002:324:71-86.

169. Kopp E, Ghosh S. Inhibition of NF-KB by sodium salicylate and aspirin. Science. 1994;265:956-9.

170. Grilli M, Pizzi M, Memo M, Spano P. Neuroprotection by aspirin and sodium salicylate through blockade of NF-kB activation. Science. 1996;274:1383-5.

171. Morris T, Stables M, Hobbs A, et al. Effects of low-dose aspirin on acute inflammatory responses in humans. J Immunol. 2009;183:2089-96.

172. Cinti A, De Giorgi M, Chisci E, et al. Simultaneous overexpression of functional human HO-1, E5NT and ENTPD1 protects murine fibroblasts against TNF-a-induced injury in vitro. PLoS One. 2015;10:e0141933. https://doi.org/10.1371/journal.pone.0141933.

173. Soares MP, Lin Y, Anrather J, et al. Expression of heme oxygenase-1 can determine cardiac xenograft survival. Nat Med. 1998:4:1073-7.

174. Petersen B, Lucas-Hahn A, Lemme E, et al. Generation and characterization of pigs transgenic for human hemeoxygenase-1 (hHO-1). Xenotransplantation. 2010;17:102-3.

175. Petersen B, Ramackers W, Lucas-Hahn A, et al. Transgenic expression of human heme oxygenase-1 in pigs confers resistance against xenograft rejection during ex vivo perfusion of porcine kidneys. Xenotransplantation. 2011;18:355-68.

176. Yeom HJ, Koo OJ, Yang J, et al. Generation and characterization of human hemeoxygenase-1 transgenic pigs. PLoS One. 2012;7:e46646.

177. Camara NO, Soares MP. Heme oxygenase-1 (HO-1), a protective gene that prevents chronic graft dysfunction. Free Radic Biol Med. 2005;38:426-35.

178. Yan JJ, Yeom HJ, Jeong JC, et al. Beneficial effects of the transgenic expression of human sTNFalphaR-fc and HO-1 on pig-to-mouse islet xenograft survival. Transpl Immunol. 2016;34:25-32.

179. Oropeza M, Petersen B, Carnwath JW, et al. Transgenic expression of the human A20 gene in cloned pigs provides protection against apoptotic and inflammatory stimuli. Xenotransplantation. 2009:16:522-34.
180. Boone DL, Turer EE, Lee EG, et al. The ubiquitin-modifying enzyme A20 is required for termination of toll-like receptor responses. Nat Immunol. 2004;5:1052-60

181. Hitotsumatsu O, Ahmad R-C, Tavares R, et al. The ubiquitin-editing enzyme A20 restricts nucleotide-binding oligomerization domain containing 2triggered signals. Immunity. 2008;28:381-90.

182. Conway EM. Thrombomodulin and its role in inflammation. Semin Immunopathol. 2012;34:107-25.

183. Conway EM, Van de Wouwer M, Pollefeyt S, et al. The lectin-like domain of thrombomodulin confers protection from neutrophil-mediated tissue damage by suppressing adhesion molecule expression via nuclear factor kappaB and mitogen-activated protein kinase pathways. J Exp Med. 2002; 196(5):565-77.

184. Esmon CT. Crosstalk between inflammation and thrombosis. Maturitas. 2004; 47:305-14.

185. Van de Wouwer M, Plaisance S, De Vriese A, et al. The lectin-like domain of thrombomodulin interferes with complement activation and protects against arthritis. J Thromb Haemost. 2006;4:1813-24.

186. Ikezoe T. Thrombomodulin/activated protein C system in specific disseminated intravascular coagulation. J Intensive Care. 2015;3(1). https:// doi.org/10.1186/s40560-014-0050-7.

187. Kim H, Hawthorne WJ, Kang HJ, et al. Human thrombomodulin regulates complement activation as well as the coagulation cascade in xeno-immune response. Xenotransplantation. 2015;22:260-72.

188. Lee KF, Lu B, Roussel JC, et al. Protective effects of transgenic human endothelial protein $C$ receptor expression in murine models of transplantation. Am J Transplant. 2012;12:2363-72.

189. Crikis S, Lu B, Murray-Segal LM, et al. Transgenic overexpression of CD39 protects against renal ischemia-reperfusion and transplant vascular injury. Am J Transplant. 2010;10:2586-95.

190. Dwyer KM, Mysore TB, Crikis S, et al. The transgenic expression of human CD39 on murine islets inhibits clotting of human blood. Transplantation. 2006:82:428-32.

191. Imai M, Takigami K, Guckelberger O, et al. Recombinant adenoviral mediated CD39 gene transfer prolongs cardiac xenograft survival. Transplantation. 2000;70:864-70.

192. Van den boogaard FE, Brands X, Schultz MJ, et al. Recombinant human tissue factor pathway inhibitor exerts anticoagulant, anti-inflammatory and antimicrobial effects in murine pneumococcal pneumonia. J Thromb Haemost. 2011;9:122-32.

193. Chinetti-Gbaguidi G, Copin C, Derudas B, et al. Peroxisome proliferatoractivated receptor $\gamma$ induces the expression of tissue factor pathway inhibitor-1 (TFPI-1) in human macrophages. PPAR Res. 2016;2016:2756781.

194. Nguyen T, Sherratt PJ, Huang HC, et al. Increased protein stability as a mechanism that enhances Nrf2-mediated transcriptional activation of the antioxidant response element. Degradation of Nrf2 by the $26 \mathrm{~S}$ proteasome. J Biol Chem. 2003;278:4536-41.

195. Yang H, Zhao P, Tian S, et al. Clopidogrel protects endothelium by hindering TNFalpha-induced VCAM-1 expression through CaMKKbeta/ AMPK/Nrf2 pathway. J Diabetes Res. 2016;2016:9128050. https://doi.org/10. 1155/2016/9128050

196. Isermann B, Vinnikov I, Madhusudhan T, et al. Activated protein C protects against diabetic nephropathy by inhibiting endothelial and podocyte apoptosis. Nat Med. 2007;13:1349-58.

197. Girard TJ, Warren LA, Novotny WF, et al. Functional significance of the Kunitz-type inhibitory domains of lipoprotein-associated coagulation inhibitor. Nature. 1989:338:518-20.

Ready to submit your research? Choose BMC and benefit from:

- fast, convenient online submission

- thorough peer review by experienced researchers in your field

- rapid publication on acceptance

- support for research data, including large and complex data types

- gold Open Access which fosters wider collaboration and increased citations

- maximum visibility for your research: over $100 \mathrm{M}$ website views per year

At $\mathrm{BMC}$, research is always in progress.

Learn more biomedcentral.com/submission 